\title{
Inequality, Human Capital Formation and the Process of Development
}

\author{
Oded Galor*
}

May 19, 2011

\begin{abstract}
Conventional wisdom about the relationship between income distribution and economic development has been subjected to dramatic transformations in the past century. While Classical economists advanced the hypothesis that inequality is beneficial for economic development, the Neoclassical paradigm, which had subsequently dominated the field of macroeconomics, dismissed the Classical hypothesis and promoted the viewpoint that the study of income distribution has no importance for the understanding of macroeconomic activity and the growth process. A metamorphosis in these perspectives has taken place in the past two decades. Theory and subsequent empirical evidence have demonstrated that income distribution has a significant impact on the growth process.

The modern approach has demonstrated that in the presence of credit market imperfections, income distribution has a long-lasting effect on investment in human capital, entrepreneurial activity, aggregate income, and economic development. Moreover, in contrast to the Classical viewpoint, which underscored beneficial effects of inequality for the growth process, the modern perspective advanced the hypothesis that inequality may be detrimental for human capital formation and economic development.

The replacement of physical capital accumulation by human capital accumulation as the prime engine of economic growth has changed the qualitative impact of inequality on the process of development. In early stages of industrialization, as physical capital accumulation was a prime source of economic growth, inequality enhanced the process of development by channeling resources towards individuals whose marginal propensity to save is higher. In later stages of development, however, as human capital has become the main engine of economic growth, a more equal distribution of income, in the presence of credit constraints, has stimulated investment in human capital and economic growth.

While the process of industrialization raised the importance of human capital in the production process, reflecting its complementarity with physical capital and technology, human capital accumulation has not benefited all sectors of the economy. Inequality in the ownership of factors of production has generated an incentive for some better-endowed agents to block the implementation of institutional changes and policies that promote human capital formation, resulting in a suboptimal level of investment in human capital from a growth perspective. The transition from an agricultural to an industrial economy changed the nature of the main economic conflict in society. Unlike the agrarian economy, which was characterized by a conflict of interests between the landed aristocracy and the masses, the process of industrialization has brought about an additional conflict between the entrenched landed elite and the emerging capitalist elite. In light of a lower degree of complementarity between human capital and the agricultural sector, education has increased the productivity of labor
\end{abstract}

\footnotetext{
*Prepared for the Handbook of the Economics of Education, North-Holland.
} 
in industrial production more than in agricultural and primary good production, inducing rural-to-urban migration and a decline in the return to landowners. Thus, while industrialists have had a direct economic incentive to support education policies that would foster human capital formation, landowners, whose interests lay in the reduction of the mobility of their labor force, have favored policies that deprived the masses of education.

The adverse effect of the implementation of public education on landowners' income from agricultural production has been magnified by the concentration of land ownership. As long as landowners affected the political process and thereby the implementation of growth-enhancing education policies, inequality in the distribution of land ownership has been a hurdle for human capital accumulation, slowing the process of industrialization and the transition to modern growth. Variation in the distribution of ownership over land and other natural resources across countries has contributed to disparity in human capital formation and the industrial composition of the economy, and thus to divergent development patterns across the globe. Moreover, in some societies geographical conditions that led to income inequality brought about oppressive institutions designed to maintain the political power of the elite and to preserve the existing inequality.

Keywords: Education, Gender Gap, Human capital, Income distribution, Inequality, Development, Unified Growth Theory

JEL Classification: 010

\section{Contents}

1 Introduction $\quad \mathbf{1}$

1.1 From the Classical to the Modern Perspective . . . . . . . . . . . . . . . 1

1.2 The Credit Market Imperfections Channel . . . . . . . . . . . . . . . . . 2

1.3 The Political Economy Channel . . . . . . . . . . . . . . . . . . . . . . 4

2 The Benchmark Model

2.1 Production of Final Output . . . . . . . . . . . . . . . . . . 5

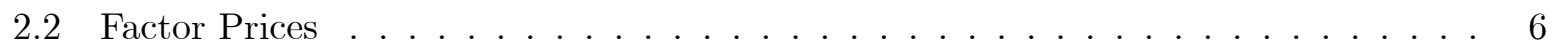

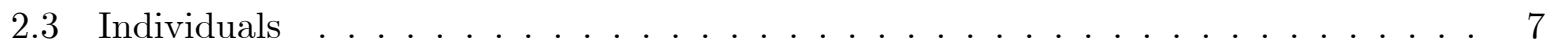

2.3.1 Preferences and Budget Constraint . . . . . . . . . . . . . 8

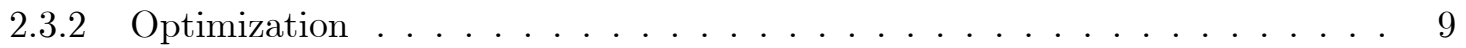

2.4 Fundamental Assumptions . . . . . . . . . . . . . . . . . . . . . . . 9

2.5 Occupational Choice . . . . . . . . . . . . . . . . . . . 10

2.5.1 Income of an Unskilled Worker . . . . . . . . . . . . . . . . . 10

2.5.2 Income of a Skilled Worker . . . . . . . . . . . . . . . . . . . 10

2.5.3 Parental Transfers and Occupational Choices . . . . . . . . . . . . . . 11

2.6 Bequest Dynamics . . . . . . . . . . . . . . . . . . . 13

2.7 Distribution, Skill Composition and Income . . . . . . . . . . . . . 16

2.7.1 Income Distribution and the Composition of Skills . . . . . . . . . . . . . 16

2.7.2 Persistence of Inequality . . . . . . . . . . . . . . . . . . . 17

2.7.3 Skill Composition and Income Per Capita . . . . . . . . . . . . . . . . . 18

2.8 Inequality and Economic Development . . . . . . . . . . . . . . . . . . 19

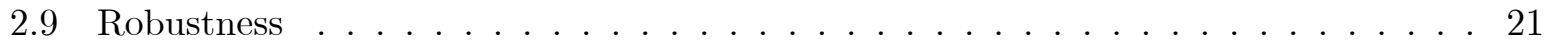

2.9.1 Labor-Augmenting Technological Progress . . . . . . . . . . . . . . . 21

2.9 .2 Interactions Across Dynasties . . . . . . . . . . . . . . . . . . 24 
2.9.3 Random Shocks . . . . . . . . . . . . . . . . . . . . . 24

2.9.4 Concave Production of Human Capital and Alternative Utility Functions . 25

3 A Unified Theory of Inequality and Growth 25

4 Non-Financial Hurdles for Human Capital Accumulation 28

4.1 Concentration of Landownership . . . . . . . . . . . . . . . . 28

4.2 Social-Political Transitions . . . . . . . . . . . . . . . . . . . 30

4.3 Gender Inequality . . . . . . . . . . . . . . . . . . . . . . 31

5 Evidence $\quad 31$

5.1 Inequality, Human Capital Formation and Economic Growth . . . . . . . . . . 31

5.2 Industrialization and Human Capital Formation . . . . . . . . . . . . . . . . 33

5.2 .1 Industrial Demand for Education . . . . . . . . . . . . . . . . 35

5.2.2 Land Concentration: A Hurdle for Human Capital Formation . . . . . . . . 41

5.2.3 Land Reforms and Education Reforms . . . . . . . . . . . . . . . 43

5.2 .4 Political and Education Reforms . . . . . . . . . . . . . . . . . 47

6 Concluding Remarks $\quad 49$

$\begin{array}{ll}\text { References } & \mathbf{5 2}\end{array}$ 


\section{Introduction}

Conventional wisdom about the relationship between income distribution and macroeconomic activity has been subjected to dramatic transformations in the past century. While Classical economists advanced the hypothesis that inequality is beneficial for economic development, the Neoclassical paradigm, which had subsequently dominated the field of macroeconomics, dismissed the Classical thesis and promoted the viewpoint that the study of income distribution has no significance for the understanding of macroeconomic activity and the growth process.

A metamorphosis in these perspectives has taken place in the past two decades. Theory and subsequent empirical evidence have demonstrated that income distribution does, in fact, have a significant impact on the growth process. Moreover, unlike the Classical viewpoint, which underlined the beneficial effects of inequality for the growth process, the modern theory has highlighted the potential adverse effects of inequality on the process of development.

\subsection{From the Classical to the Modern Perspective}

The Classical approach advanced the hypothesis that inequality is beneficial for economic development in the post-industrialization period (Kaldor, 1955). ${ }^{1}$ It suggests that since the marginal propensity to save increases with wealth, inequality channels resources towards individuals whose marginal propensity to save is higher, increasing aggregate savings, capital accumulation, and economic growth. ${ }^{2}$ The Classical hypothesis, however, was implicitly dismissed by the representative agent paradigm that had dominated the field of macroeconomics. The influential Neoclassical approach rejected the relevance of heterogeneity, and thus the distribution of income, for macroeconomic analysis. It implicitly interpreted the observed relationship between inequality and economic growth as capturing the effect of the growth process on the distribution of income. ${ }^{3}$

The Neoclassical viewpoint has been challenged in the past two decades, as both theories and subsequent empirical evidence have demonstrated that income distribution has a significant

\footnotetext{
${ }^{1}$ Development economists advanced an additional hypothesis about the relationship between inequality and economic development that is largely tangential to the understating of this association in the modern, postindustrialization era. As argued by Rosenstein-Rodan (1943), Lewis (1954), Baldwin (1956), and North (1959), and formulated by Murphy et al. (1989), in the absence of international demand for domestic industrial goods, a wide distribution of the income generated from the leading agricultural sector may be critical for industrialization.

${ }^{2}$ Echoing the insight of the Classical economists, it was established that within a Neoclassical growth model with a convex saving function, the distribution of income might lead to either an equalitarian or unequal distribution of income in the long-run (Stiglitz, 1969), where the less egalitarian equilibrium is superior (Bourguignon, 1981).

${ }^{3}$ This viewpoint can be traced to the hypothesis advanced by Kuznets (1955), according to which, the inverted $\mathrm{U}$ relationship between inequality and economic development that he found reflects a causation from the process of development to the distribution of income.
} 
impact on the growth process. In contrast to the representative agent approach which dominated the field of macroeconomics for several decades, the modern perspective, originated by Galor and Zeira $(1988,1993)$, has underlined the role of heterogeneity in the determination of macroeconomic activity. It has advanced a novel viewpoint that heterogeneity, and thus income distribution, plays an important role in the determination of aggregate economic activity and economic growth in the short run as well as in the long run.

Galor and Zeira have demonstrated that in the presence of credit market imperfections income distribution has a long-lasting effect on investment in human capital, aggregate income, and economic development. Moreover, in contrast to the Classical hypothesis, which underscored the virtues of inequality for economic growth, their research advanced the hypothesis that inequality may be detrimental for human capital formation and economic development.

The modern perspective about the relationship between inequality and economic development has subsequently emerged, resulting in a voluminous body of research that have highlighted the adverse effect of inequality on the process of development. ${ }^{4}$ The initial research has been widely classified into two broad approaches for the examination of the relationship between inequality and growth: the credit market imperfection approach and the political economy approach. ${ }^{5}$

\subsection{The Credit Market Imperfections Channel}

The credit market imperfection approach for the study of income distribution and economic growth has explored the implications and the robustness of the effect of inequality on the process of development in the presence of credit market imperfections.

Galor and Zeira have demonstrated that in the presence of credit market imperfections and fixed costs associated with investment in education, occupational choices (and thus the efficient segmentation of the labor force between skilled and unskilled workers) are affected by the distribution of income. In particular, if the interest rate for borrowers is higher than that for lenders, inequality may result in an under-investment in human capital. ${ }^{6}$ Inequality may

\footnotetext{
${ }^{4}$ This chapter, written from a macro-growth perspective, focuses on the literature that explores the effect of inequality on the development process, rather than on the forces that prevent (Loury, 1981) or generate persistent inequality within an economy (Benabou, 1996; Durlauf, 1996a; Fernández and Rogerson, 1996; Mookherjee and Ray, 2003) or across economies (Galor and Mountford, 2008; Galor, 2010).

${ }^{5}$ An additional line of research that has generated less attention examined the effect of inequality on aggregate demand, innovations, and growth, in the presence of non-homothetic preferences (Chou and Talmain, 1996; Matsuyama, 2000; Foellmi and Zweimuller, 2006).

${ }^{6}$ Although the provision of public education mitigates the effect of inequality on human capital formation, the
} 
therefore adversely affect macroeconomic activity and economic development in the short-run, and due to intergenerational transfers and their effect on the persistence of inequality, it may generate a detrimental effect on economic development in the long-run as well. ${ }^{7}$

The credit market imperfection approach for the study of the effects of income distribution on economic growth, which has subsequently emerged, maintained the two fundamental assumptions of the Galor-Zeira model (i.e., credit market imperfections and fixed costs associated with individual-specific investment projects), establishing the robustness of the main hypothesis. ${ }^{8}$ Notably, Banerjee and Newman (1993) examine the effect of inequality on a different type of occupational choices - the choice between becoming an entrepreneur or a worker. They demonstrate that if credit markets are imperfect and fixed costs are associated with entrepreneurial activities, inequality may result in an under-investment in entrepreneurial activity and may therefore be harmful for economic development. ${ }^{9}$ Furthermore, they establish that as long as wages are endogenous, the main hypothesis of the credit market imperfection approach is robust to the introduction of random shocks to the outcome of investment (in human capital or entrepreneurial activities). ${ }^{10}$

The interplay between income inequality and equality of opportunities that has been underlined by Galor and Zeira led to an additional strand of research within the credit market imperfection approach. This research examines the effect of inequality on the degree of intergenerational mobility and thus the efficiency in the allocation of talents across occupations (Fershtman et al., 1996; Owen and Weil, 1998; Maoz and Moav, 1999; Checchi et al., 1999;

adverse effect is still maintained due to the differential effect of inequality on: (i) the importance of forgone earnings in education decisions, (ii) the allocation of parental inputs in the production of the children's human capital (Galor and Tsiddon, 1997b), (iii) the ability of parents to optimally select the schooling environment for their children (Benabou, 1996; Durlauf, 1996a; Fernández and Rogerson, 1996), and (iv) assortative mating (Fernández and Rogerson, 2001;Fernandez et al., 2005). Moreover, it should be noted that while the positive effect of wage inequality on the incentive to invest in human capital may counterbalance the adverse effect of limited parental resources on investment in human capital in the lower tail of the income distribution, other forms of inequality (e.g., wealth inequality and inequality in the distribution of income between capital, land and labor) do not affect the incentive to invest in human capital.

${ }^{7}$ In contrast, in sufficiently poor economies, where the fixed cost of education is high in comparison to the level of income per capita, inequality may permit at least members of the upper tail of the income distribution to undertake investment in human capital. Hence, higher inequality would be expected to be associated with higher investment in education.

${ }^{8}$ The Galor-Zeira setup was further exploited by Quah (1996) to shed light on the emergence of convergence clubs (and thus persistent inequality) in the world economy, in the presence of imperfect capital mobility across economies.

${ }^{9}$ Aghion and Bolton (1997) further demonstrate that redistribution improves the efficiency of the economy, because it enhances equality of opportunity and the trickle-down process from the rich to the poor.

${ }^{10}$ See also Piketty (1997). 
Hassler et al., 2007). ${ }^{11}$

Furthermore, the interaction between income inequality and credit market imperfections was placed at the center of an important literature that examines the relationship between segregation and persistent inequality. ${ }^{12}$ These studies have demonstrated that in the presence of credit market imperfections, inequality enhances segregation across communities and thus, in the light of local externalities in the production of human capital, it may generate persistent education and income gaps (Benabou, 1996; Durlauf, 1996a, 1996b; Fernández and Rogerson, 1996). ${ }^{13}$

\subsection{The Political Economy Channel}

The political economy approach for the study of the relationship between inequality and economic growth further advanced the viewpoint that inequality is harmful for economic development. Earlier studies have argued that inequality generates a pressure to adopt redistributive policies, and the distortions associated with these policies adversely affect investment in physical and human capital and thus the growth process.

These studies have suggested that in societies that are characterized by inequality, distributional conflicts may bias political decisions in favor of appropriation. Hence, since the incentives for productive accumulation of physical capital, human capital, and knowledge hinge on the ability of individuals to privately appropriate the return on their investment, inequality may diminish investment and economic growth. In particular, using the median voter paradigm, it was hypothesized that in a more equitable society, taxation on physical capital (Alesina and Rodrik, 1994) and human capital (Persson and Tabellini, 1994) is lower, limiting the degree of distortions in investment decisions, and promoting economic growth.

In light of the inconsistency of this mechanism with empirical evidence (Perotti, 1996), subsequent theories advanced the thesis that inequality may in fact generate an incentive for better-endowed agents to lobby against redistribution, preventing efficient redistribution policies from being implemented (Saint-Paul and Verdier, 1996; Benabou, 2000, 2002). Moreover, others have examined the long-run effects of inequality in the ownership of factors of production on

\footnotetext{
${ }^{11}$ The adverse effect of inequality on occupational choices and intergenerational mobility is robust to the removal of credit market imperfections as long as parental human capital and social background are introduced into the analysis (Galor and Tsiddon, 1997a, 1997b;Hassler and Mora, 2000; Zilcha, 2003; Mejía and St-Pierre, 2008; Brezis and Temin, 2008).

${ }^{12}$ In an influential study, Loury (1981), have underlined the lack of persistence of inequality, despite credit market imperfections.

${ }^{13}$ Eicher et al. (2009) examines the interaction between inequality, corruption and education.
} 
the incentive for better-endowed agents to block the implementation of institutional changes and policies that promote human capital formation and thus economic growth (Engerman and Sokoloff, 2000; Galor et al., 2009).

\section{The Benchmark Model}

The basic framework of analysis for the effect on inequality on income per capita is the Galor-Zeira model. The model demonstrates that under plausible conditions (i.e., credit market imperfections and fixed costs in the acquisition of human capital), income distribution has a long lasting effect on investment in human capital, aggregate income, and the development process. ${ }^{14}$ In particular, if the interest rate for borrowers is higher than that for lenders, as is universally the case, the distribution of income affects occupational choices (and thus the efficient segmentation of the labor force between skilled and unskilled workers), and it may result in an under-investment in human capital. Inequality may therefore adversely affect macroeconomic activity and economic development in the short-run, and due to intergenerational transfers and their effect on the persistence of inequality, it may adversely affect economic development in the long-run as well.

Consider a small open overlapping-generations economy in which economic activity extends over infinite discrete time. In every period the economy produces a single homogeneous good that can be used for consumption and investment. The good is produced in two sectors using capital, skilled labor and unskilled labor in the production process. The stock of physical capital in every period is formed by aggregate domestic saving in the preceding period, net of international lending, whereas the segmentation of the labor force between skilled and unskilled labor in every period is the outcome of individuals' education decisions in an environment characterized by credit market imperfections.

\subsection{Production of Final Output}

Production occurs within a period. The output produced in the domestic economy at time $t, Y_{t}$, is the sum of the output produced in the skilled labor-intensive sector, $Y_{t}^{s}$, and the unskilled labor-intensive sector, $Y_{t}^{u}$. Namely,

$$
Y_{t}=Y_{t}^{s}+Y_{t}^{u}
$$

\footnotetext{
${ }^{14}$ The main hypothesis of the credit market imperfection approach is robust, however, to the removal of the assumption of a fixed cost of education or investment projects, as long as savings are an increasing function of wealth (Moav, 2002; Galor and Moav, 2004).
} 
The output produced in the skilled labor-intensive sector is governed by a neoclassical constant-returns-to-scale production technology,

$$
Y_{t}^{s}=F\left(K_{t}, L_{t}^{s}\right) \equiv L_{t}^{s} f\left(k_{t}\right) ; \quad k_{t} \equiv K_{t} / L_{t}^{s},
$$

where $K_{t}$ and $L_{t}^{s}$ are the quantities of physical capital and skilled labor employed in production at time $t$. Capital depreciates fully within a period. ${ }^{15}$ The intensive production function, $f\left(k_{t}\right)$, is monotonically increasing, strictly concave in $k_{t}$, and satisfies the neoclassical boundary conditions that assure the existence of an interior level of $k_{t}$ that maximizes profit.

The output produced in the unskilled-intensive sector is governed by a linear production technology that converts the input of unskilled labor into final output. In particular,

$$
Y_{t}^{u}=a L_{t}^{u}
$$

where $a>0$ is the marginal productivity of unskilled labor in the production of final output.

Producers operate in a perfectly competitive environment. Given the interest rate, $r_{t}$, and the wage rate of skilled labor, $w_{t}^{s}$, producers in the skilled labor-intensive sector in period $t$ choose the level of employment of capital, $K_{t}$, and the skilled labor, $L_{t}^{s}$, so as to maximize profits. That is,

$$
\left\{K_{t}, L_{t}^{s}\right\}=\arg \max \left[L_{t}^{s} f\left(k_{t}\right)-w_{t}^{s} L_{t}^{s}-r_{t} K_{t}\right]
$$

The producers' inverse demand for factors of production is therefore

$$
\begin{aligned}
& r_{t}=f^{\prime}\left(k_{t}\right) \equiv r\left(k_{t}\right) \\
& w_{t}^{s}=f\left(k_{t}\right)-f^{\prime}\left(k_{t}\right) k_{t} \equiv w^{s}\left(k_{t}\right) .
\end{aligned}
$$

Similarly producers in the unskilled labor-intensive sector demand labor as long as the wage of an unskilled laborer does not exceed its productivity, $a$. The demand for unskilled labor in this sector in period $t$ is therefore perfectly elastic at the wage level $w_{t}^{u}=a$.

\section{$2.2 \quad$ Factor Prices}

Suppose that capital is perfectly mobile internationally and the world interest rate is constant over time at level $r>0$. Producers can borrow and individuals can lend unlimited funds at this rate at the world market.

\footnotetext{
${ }^{15}$ Imperfect capital depreciation has no effect on the qualitative results.
} 
The interest rate in the domestic economy in period $t, r_{t}$, is therefore equal to the constant world interest rate $r$, i.e.,

$$
r_{t}=r .
$$

In particular, if the entire aggregate saving in the domestic economy would have been channeled towards the domestic production and would have generated a marginal productivity of capital that exceeds the world interest rate, international capital would flow into the domestic economy till the marginal productivity of capital in the domestic economy would be equal to the world interest rate. However, if the entire aggregate saving in the domestic economy would have been channeled towards the domestic production and would have generated a marginal productivity of capital that would be lower than the world interest rate, domestic savings would flow into the world economy until the marginal productivity of capital in the domestic economy would be equal to the world interest rate.

International capital mobility implies therefore that the ratio of capital to skilled-labor employed in production, $k_{t}$ is constant over time. In particular, as follows from (5) and (6),

$$
k_{t}=f^{\prime-1}(r) \equiv k,
$$

and thus the wage of an skilled worker,

$$
w_{t}^{s}=w^{s}(k) \equiv w^{s}
$$

is constant over time at a level $w^{s}$.

Furthermore, the perfectly elastic demand for unskilled labor in the unskilled-intensive sector implies that as long as unskilled labor is present in the economy,

$$
w_{t}^{u}=a \equiv w^{u} .
$$

\subsection{Individuals}

In every period a generation which consists of a continuum of individuals of measure one is born. Each individual has a single parent and a single child. Individuals, within as well as across generations, are identical in their preferences and innate abilities. They may differ, however, in their family wealth and thus, due to imperfect capital markets, in their investment in human capital. ${ }^{16}$

\footnotetext{
${ }^{16}$ The introduction of population growth does not affect the qualitative results.
} 
Individuals live for two periods. In the first period of life (childhood) an individual can either join the labor force as an unskilled worker or devote time to a costly acquisition of human capital. Their consumption in this period is an integral part of parental consumption.

Individuals receive a parental transfer (bequest) towards the end of the period. Those who choose to become skilled workers, channel the parental transfer towards the cost of education. If parental transfer is insufficient to cover the entire cost of education they can access an imperfect capital market and borrow the remaining part at the borrowers' interest rate. If parental transfer exceeds the cost of education, the excess is saved for the second period of life at the lender interest rate. In contrast, individuals who choose to join the labor market directly as unskilled workers save their parental transfer and their wage income for adulthood.

In the second period of their lives (adulthood), individuals who did not acquire education in the first period of life continue to work as unskilled workers, whereas those who acquired education join the labor force as skilled workers. All individuals allocate their wage income and the returns on their savings between family consumption and capital transfers to their children.

\subsubsection{Preferences and Budget Constraint}

Preferences of an individual who is born in period $t$ (a member of generation $t$ ) are defined over household consumption in adulthood, $c_{t+1}$, and over the intergenerational transfer (bequest) to the offspring, $b_{t+1}$. The preferences are represented by a log-linear utility function,

$$
u_{t}=\alpha \log c_{t+1}+(1-\alpha) \log b_{t+1},
$$

where $\alpha \in(0,1) .{ }^{17}$

The budget constraint of a member of generation $t$ during adulthood is therefore

$$
c_{t+1}+b_{t+1} \leq \omega_{t+1}
$$

where the level of wealth of individual $t$ in the second period of life, $\omega_{t+1}$, reflects the parental transfer and occupational decisions made in the first period of life. It consists of the individual's wage income in the second period of life net of loan repayments, capital income on savings, and wealth carried from the first period of life.

\footnotetext{
${ }^{17}$ This utility function reflects the joy of giving. As established in the robustness section, the qualitative analysis will not be affected if preferences are defined over the utility of the offspring.
} 


\subsubsection{Optimization}

In the second period life (adulthood), individuals allocate their second period wealth, $\omega_{t+1}$, between consumption, $c_{t+1}$, and bequest, $b_{t+1}$, so as to maximize their utility function subject to their second period budget constraint:

$$
\begin{gathered}
\left\{c_{t+1}, b_{t+1}\right\}=\arg \max \left[\alpha \ln c_{t+1}+(1-\alpha) \ln b_{t+1}\right] \\
\text { subject to: } \quad c_{t+1}+b_{t+1} \leq \omega_{t+1} .
\end{gathered}
$$

Hence, a fixed fraction, $\alpha$, of their second period wealth, $\omega_{t+1}$, is devoted to consumption and the remaining fraction, $(1-\alpha)$, is devoted to bequest, i.e.,

$$
\begin{aligned}
& c_{t+1}=\alpha \omega_{t+1} ; \\
& b_{t+1}=(1-\alpha) \omega_{t+1} .
\end{aligned}
$$

Moreover, the indirect utility function of members of generation $t, v_{t}$ (i.e., the level of utility generated by the optimal choices of $c_{t+1}$ and $\left.b_{t+1}\right)$ is monotonically increasing in their second period wealth, $\omega_{t+1}$, i.e.,

$$
v_{t}=[\alpha \ln \alpha+(1-\alpha) \ln (1-\alpha)]+\ln \omega_{t+1}
$$

Thus, an occupational choice in the first period of life that maximizes the individual's second period wealth, $\omega_{t+1}$, maximizes the individual's utility.

\subsection{Fundamental Assumptions}

The effect of the distribution of income on occupational choices and macroeconomic activity in the short-run is generated by the presence of credit market imperfections, whereas the long-run effects of income distribution on macroeconomic activity is triggered by a fixed cost associated with acquisition of human capital.

Suppose that credit markets are imperfect. While individuals can lend unlimited funds at the world interest rate, $r$, the interest rate for individuals who wish to borrow in order to invest in human capital is higher than $r$, reflecting monitoring cost designed to avoid default and the inability of human capital to serve as a tangible collateral for the loan. ${ }^{18}$ Hence

$$
r<i
$$

\footnotetext{
${ }^{18}$ Due to reputation and the cost of mobility, firms are assumed to be unable to evade debt payment and thus they can borrow at the world interest rate $r$. This simplifying assumption has no bearing on the qualitative results.
} 
where $r$ is the interest rate paid to lenders and $i$ is the interest rate on loans that are designed to finance investment in human capital.

Suppose further that the acquisition of education is associated with a fixed cost, $c^{h}=$ $h{ }^{19}$ This fixed cost may reflects the indivisibility of human capital formation in general and of academic degrees in particular. ${ }^{20}$ The fixed cost of education can be viewed as a weighted average of the payments to teachers, administrators, and maintenance workers in the school system (i.e., a weighted average of the wages of skilled and unskilled workers). In particular,

$$
c^{h}=\theta w^{s}+(1-\theta) w^{u} \equiv h>0,
$$

for some $\theta \in[0,1]$.

\subsection{Occupational Choice}

In the first period of life individuals make an occupational choice. They can either acquire education and work in adulthood as skilled workers, or join the labor force directly as unskilled worker and remain unskilled in adulthood.

\subsubsection{Income of an Unskilled Worker}

An individual $t$ who decides to join the labor force directly as an unskilled worker earns in the first period of life the wage of an unskilled worker, $w^{u}$. In addition, in the end of the first period, the individual receives a bequest of $b_{t}$. Since consumption in childhood is an intrinsic part of the household consumption, these resources are saved for adulthood. In the second period of life (adulthood) the individual's wealth consists of first period saving, $w^{u}+b_{t}$, capital income on the saving, $\left(w^{u}+b_{t}\right) r$, in addition to their second period wage income, $w^{u}$. Hence the second period wealth, $\omega_{t+1}^{u}$, of an unskilled member of generation $t$ who receive an inheritance, $b_{t}$, is

$$
\omega_{t+1}^{u}=w^{u}(2+r)+(1+r) b_{t} \equiv \omega^{u}\left(b_{t}\right) .
$$

\subsubsection{Income of a Skilled Worker}

An individual $t$ who decides to acquire education and to join the labor force in the second period of life as a skilled worker earns in the second period of life the wage of a skilled worker, $w^{s}$. The

\footnotetext{
${ }^{19}$ As underlined in section 2.9 , the main hypothesis is robust, however, to the removal of the assumption of a fixed cost of education or investment projects, as long as savings are an increasing function of wealth.

${ }^{20}$ This indivisibility is reflected in a discrete jump in the return to high school graduates versus high school dropouts, or in the return to college graduates versus college dropouts.
} 
wealth of the individual in period $t+1, \omega_{t+1}^{s}$, depends on whether parental transfers in the first period of life, $b_{t}$, are sufficient to cover the cost of education, $h$. If $b_{t}<h$ the individual borrows in the first period of life the additional required funds, $\left(h-b_{t}\right)$, and repays the loan along with the interest rate for borrowers, $i$, from the wage income in the second period of life. If, however, $b_{t}>h$ the individual finances the entire cost of education using the parental transfer, saving the excess funds, $\left(b_{t}-h\right)$. In the second period of life the individual wealth consists of wage income, $w^{s}$, saving, $b_{t}-h$, and capital income $\left(b_{t}-h\right) r$.

Hence the second period wealth, $\omega_{t+1}^{s}$, of a skilled member of generation $t$ who receive an inheritance, $b_{t}$, is

$$
\omega_{t+1}^{s}=\omega^{s}\left(b_{t}\right) \equiv\left\{\begin{array}{lll}
w^{s}-\left(h-b_{t}\right)(1+i) & \text { if } \quad b_{t} \leq h \\
w^{s}+\left(b_{t}-h\right)(1+r) & \text { if } & b_{t} \geq h .
\end{array}\right.
$$

or equivalently,

$$
\omega_{t+1}^{s}=\omega^{s}\left(b_{t}\right) \equiv\left\{\begin{array}{lll}
w^{s}-(1+i) h+(1+i) b_{t} & \text { if } \quad b_{t} \leq h \\
w^{s}-(1+r) h+(1+r) b_{t} & \text { if } \quad b_{t} \geq h .
\end{array}\right.
$$

\subsubsection{Parental Transfers and Occupational Choices}

A member of generation $t$ who receive an inheritance, $b_{t}$, acquires education if

$$
\omega_{t+1}^{s}=\omega^{s}\left(b_{t}\right)>\omega_{t+1}^{u}=\omega^{u}\left(b_{t}\right)
$$

Hence, the desirability of investment in human capital for a member of generation $t$ depends on the individual's level of inheritance, $b_{t}$.

Since individuals are identical in their abilities and the only ex-ante source of heterogeneity among individuals is parental income, the presence of skilled and unskilled workers in society in every time period would require an additional assumptions. In particular, if investment in human capital is profitable even for individuals who ought to finance the entire cost of education via borrowing, then counter-factually, all individuals would invest in human capital. Furthermore, if investment in human capital is not profitable even for those who can finance the entire cost of education from parental transfer, then counter-factually, no individual will invest in human capital. 
Thus, suppose that investment in human capital is beneficial for individuals who can finance the entire cost of education without borrowing, i.e.,

$$
w^{s}-(1+r) h>w^{u}(2+r)
$$

and suppose it is detrimental for individuals who must finance the entire cost of education via borrowing, i.e., ${ }^{21}$

$$
w^{s}-(1+i) h<0
$$

As follows from (15) and (17), and as depicted in Figure 1, $\omega^{s}(0)<0<\omega^{u}(0)$ (Assumption 2.A4), $\omega^{s}\left(b_{t}\right)>\omega^{u}\left(b_{t}\right)$ for all $b_{t} \geq h$ (Assumption 2.A3), and there exists a level of bequest, $f$, such that

$$
\omega_{t+1}^{s}=\omega^{s}(f)=\omega_{t+1}^{u}=\omega^{u}(f),
$$

where

$$
f \equiv \frac{w^{u}(2+r)-\left[w^{s}-(1+i) h\right]}{i-r}>0
$$

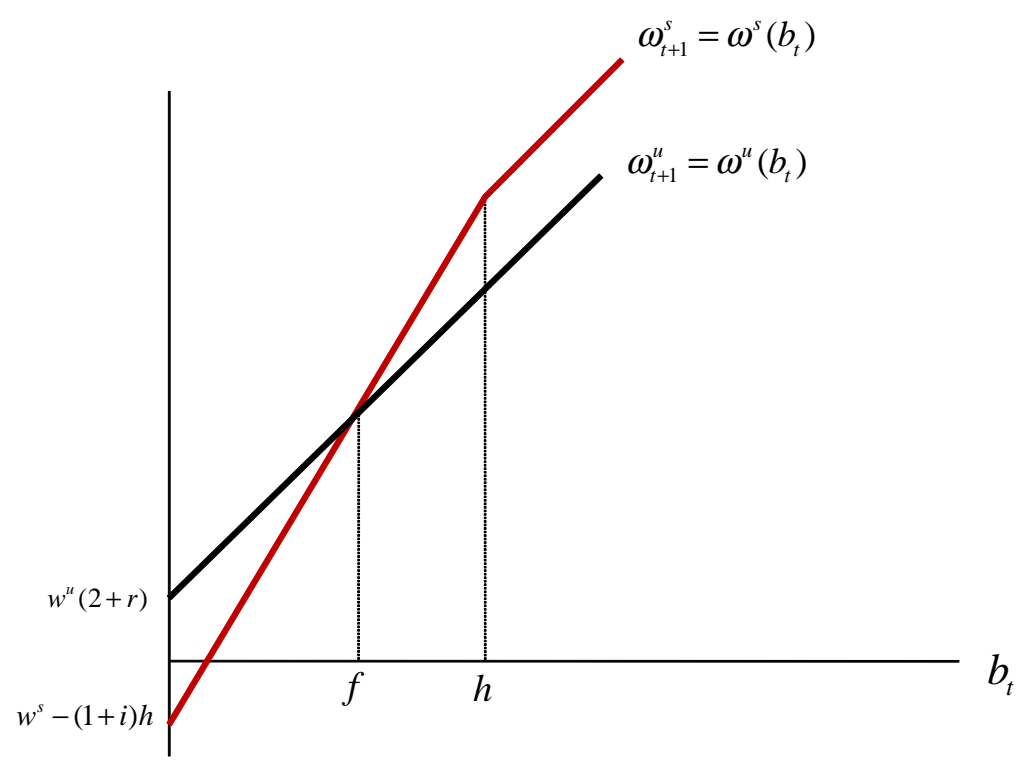

Figure 1. The Threshold Level of Bequest, $f$, above which Investment in Human Capital is Profitable

\footnotetext{
${ }^{21}$ At this stage of the analysis, it is sufficient to assume that $w^{s}-(1+i) h<w^{u}(2+r)$. However as will become apparent, the existence of multiple steady-state equilibria in the dynamics of bequests necessitates a stronger assumption, i.e., $w^{s}-(1+i) h<0$.
} 
Hence, members of generation $t$ choose to acquire education if they receive parental transfer, $b_{t}$ that exceeds that threshold level $f$. Namely,

$$
\omega_{t+1}^{s}=\omega^{s}\left(b_{t}\right)>\omega_{t+1}^{u}=\omega^{u}\left(b_{t}\right) \quad \text { if and only if } \quad b_{t}>f
$$

Thus, income distribution affects occupational choices in the short-run. Let the distribution of inheritance at time $t$ be $D_{t}\left(b_{t}\right)$, i.e.,

$$
\int_{0}^{\infty} D_{t}\left(b_{t}\right) d b_{t}=L_{t} \equiv 1
$$

where $L_{t} \equiv 1$ is the size of the adult generation in period $t$. It follows that the fraction of the adult generation in period $t+1$ that choose to become unskilled workers, $l_{t+1}^{u}$, and the fraction that choose to become skilled workers, $l_{t+1}^{s}$, are

$$
\begin{aligned}
& l_{t+1}^{u}=\int_{0}^{f} D_{t}\left(b_{t}\right) d b_{t}, \\
& l_{t+1}^{s}=\int_{f}^{\infty} D_{t}\left(b_{t}\right) d b_{t} .
\end{aligned}
$$

Hence, the distribution of income in period $t$ directly determines the segmentation of the adult generation in periods $t+1$ between skilled and unskilled workers, affecting the level of income per capita in this period. ${ }^{22}$

\subsection{Bequest Dynamics}

The long-run effects of the distribution of income on the process of development and macroeconomic activities is determined by the interaction between occupational choices and the evolution of bequest.

As follows from the solution to the individual's optimization (13), members of generation $t$ transfer a fraction $(1-\alpha)$ of their wealth, $\omega_{t+1}$, to their offspring. That is

$$
b_{t+1}=(1-\alpha) \omega_{t+1},
$$

where

$$
\omega_{t+1}=\left\{\begin{array}{lll}
\omega_{t+1}^{u}=\omega^{u}\left(b_{t}\right) & \text { if } & b_{t} \leq f \\
\omega_{t+1}^{s}=\omega^{s}\left(b_{t}\right) & \text { if } & b_{t}>f .
\end{array}\right.
$$

Hence, the inheritance received by members of generation $t$ determines their occupational choices, wealth, and the level of bequest to their offspring.

\footnotetext{
${ }^{22}$ In addition, it affects that fraction of the younger generation that joins the labor force as unskilled workers at time $t$.
} 
The evolution of bequest is determined by the sequence $\left\{b_{t}\right\}_{t=0}^{\infty}$ such that, as follows from the definition of $\omega^{u}\left(b_{t}\right)$ and $\omega^{s}\left(b_{t}\right)$ given by (15) and (17),

$$
b_{t+1}=\phi\left(b_{t}\right) \equiv \begin{cases}(1-\alpha)\left[w^{u}(2+r)+(1+r) b_{t}\right] & \text { if } \quad 0 \leq b_{t} \leq f \\ (1-\alpha)\left[w^{s}-(1+i) h+(1+i) b_{t}\right] & \text { if } \quad f \leq b_{t} \leq h \\ (1-\alpha)\left[w^{s}-(1+r) h+(1+r) b_{t}\right] & \text { if } \quad h \leq b_{t} .\end{cases}
$$

Hence the dynamical system is piecewise linear. In particular, if

$$
\begin{aligned}
& (1-\alpha)(1+r)<1 \\
& (1-\alpha)(1+i)>1
\end{aligned}
$$

then

$$
\phi^{\prime}\left(b_{t}\right) \equiv\left\{\begin{array}{lll}
(1-\alpha)(1+r)<1 & \text { if } & 0 \leq b_{t}<f \\
(1-\alpha)(1+i)>1 & \text { if } & f<b_{t}<h \\
(1-\alpha)(1+r)<1 & \text { if } & h<b_{t}
\end{array}\right.
$$

The dynamical system is characterized by multiple locally stable steady-state equilibria, as depicted in Figure 2, under additional restrictions on the parameters of the model. ${ }^{23}$

\footnotetext{
${ }^{23}$ Since $\phi(0)=(1-\alpha) w^{u}(2+r)>0$ and since $\phi^{\prime}\left(b_{t}\right)<1$ for $b_{t} \geq h$, multiplicity of locally stable steady-state equilibria is guaranteed if $\phi(f)<f$ and $\phi(h)>h$. Namely, if $w^{u}(2+r)[(1-\alpha)(1+i)-1]<\left[(1+i) h-w^{s}\right][1-$ $(1-\alpha)(1+r)]$ and $(1-\alpha) w^{s}>h$.
} 


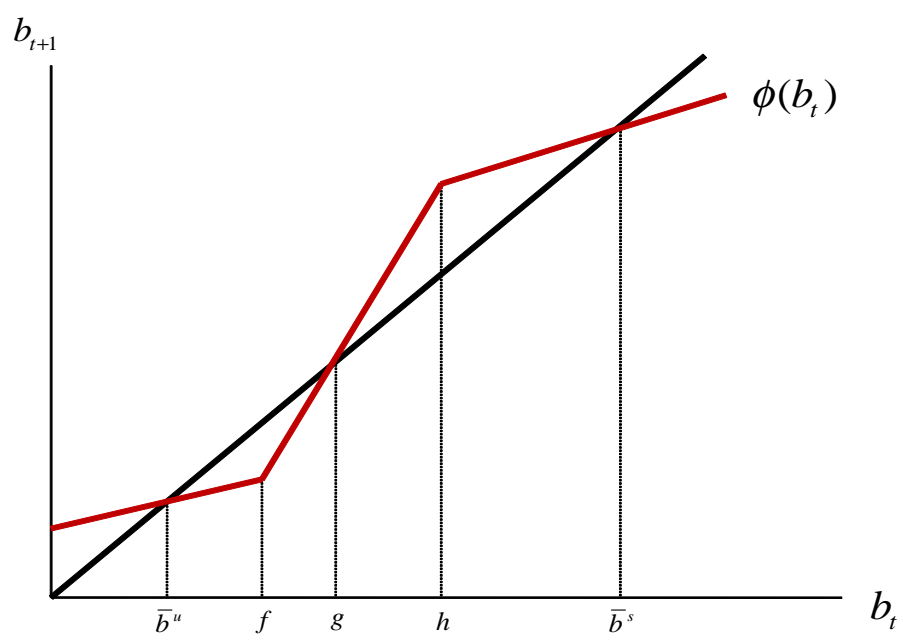

Figure 2. Bequest Dynamics:

Multiple Steady-State Equilibria in Intergenerational Transfers

Dynasties whose initial levels of intergenerational transfers are below $g$ converge in the long-run to the lower steady-state equilibrium level, $\bar{b}^{u}$, where the level of parental transfers are insufficient to permit investment in human capital by offspring. In contrast, dynasties whose initial level of intergenerational transfers is above $g$ permit investment in human capital by offspring and the levels of intergenerational transfer among members of those dynasties converge in the long-run to the higher steady-state equilibrium level, $\bar{b}^{s}$. In particular,

$$
\lim _{t \rightarrow \infty} b_{t}=\left\{\begin{array}{llr}
\bar{b}^{u} \equiv \frac{(1-\alpha) w^{u}(2+r)}{1-(1-\alpha)(1+r)} & \text { if } & b_{t}<g \\
\bar{b}^{s} \equiv \frac{(1-\alpha)\left[w^{s}-(1+r) h\right]}{1-(1-\alpha)(1+r)} & \text { if } & b_{t}>g .
\end{array}\right.
$$

The level of bequest that determines the segmentation of society between educated and uneducated individuals as well as the segmentation of the labor force in the long-run is

$$
g \equiv \frac{(1-\alpha)\left[(1+i) h-w^{s}\right]}{(1-\alpha)(1+i)-1}
$$

as can be derived from (26), where $g>0$ as follows from Assumptions 2.A4 and 2.A5. 
The threshold level of bequest, $g$, above which investment in human capital is beneficial for members of the dynasty in the long-run is lower if (a) the cost of education, $h$, is lower, (b) the wage of a skilled worker, $w^{s}$, and thus the incentive to become a skilled worker is higher, (c) the interest rate for borrowers, $i$, is lower, or (d) the propensity of individuals to bequeath, $(1-\alpha)$, is higher. ${ }^{24}$

\subsection{Distribution, Skill Composition and Income}

\subsubsection{Income Distribution and the Composition of Skills}

Given the distribution of inheritance at time $t, D_{t}\left(b_{t}\right)$, the critical level of bequest, $g$, determines the long-run composition of the labor force. As depicted in Figure 3, the fraction of each generation that in the long-run becomes unskilled workers, $\bar{l}^{u}$, and skilled workers, $\bar{l}^{s}$, is

$$
\begin{aligned}
\lim _{t \rightarrow \infty} l_{t+1}^{u} & =\int_{0}^{g} D_{t}\left(b_{t}\right) d b_{t} \equiv \bar{l}^{u} ; \\
\lim _{t \rightarrow \infty} l_{t+1}^{s} & =\int_{g}^{\infty} D_{t}\left(b_{t}\right) d b_{t} \equiv \bar{l}^{s},
\end{aligned}
$$

where

$$
\partial \bar{l}^{s} / \partial g<0
$$

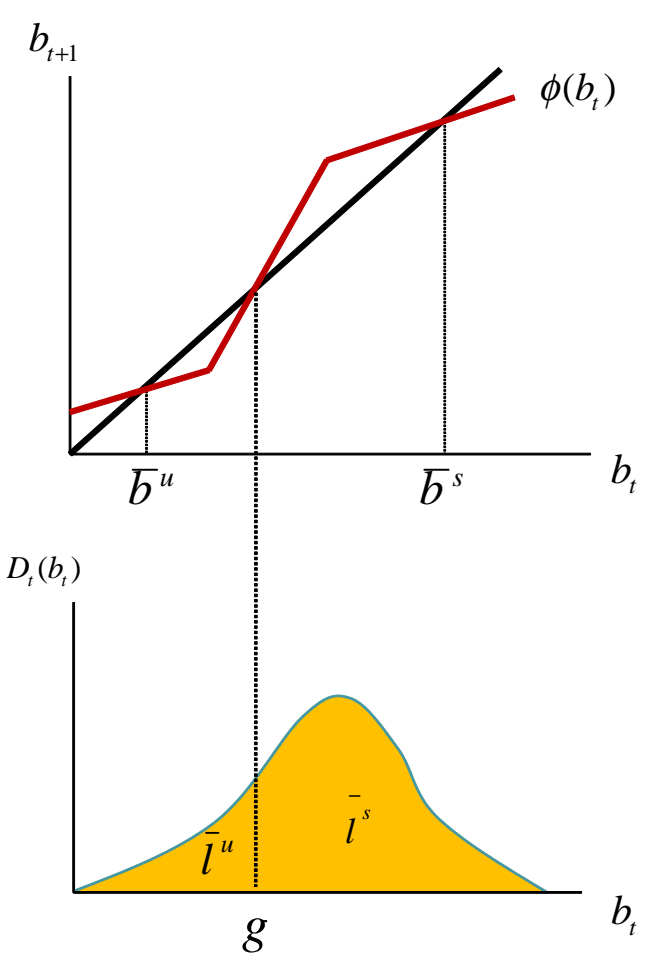

Figure 3. Income Distribution and Skill Composition.

\footnotetext{
${ }^{24}$ Note that $\partial g / \partial(1-\alpha)<0$ if Assumption 2.A4 is satisfied.
} 
Thus, the distribution of income determines not only the composition of skills and macroeconomic activities in the short-run, but via its effect on future intergenerational transfers, it also affects the composition of skills and macroeconomic activity in the long-run. Moreover, inequality persists over time and the distribution of income tends towards bimodality.

\subsubsection{Persistence of Inequality}

The initial distribution of income affects occupational choices, and the distribution of income in the short-run. However, as demonstrated in Figure 4, the interaction between occupational choices and intergenerational transfers affects occupation choices and the distribution of income in the long-run as well.
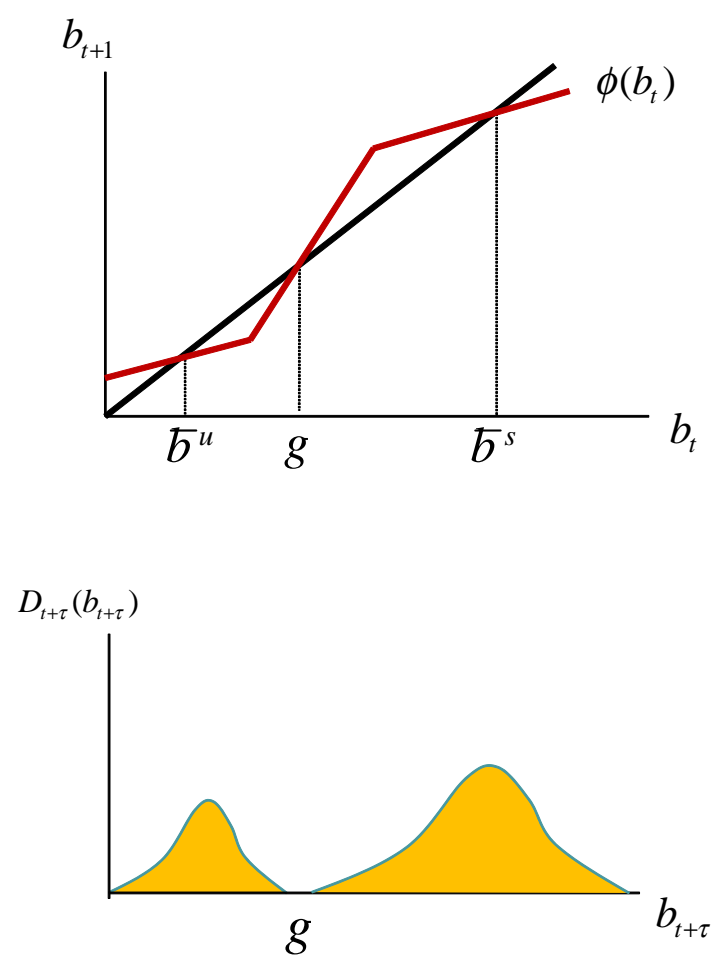

Figure 4. Persistence of Inequality

While heterogeneity of ability may permit upward mobility of high ability, low income individuals and downward mobility of low ability, high income inequality, income inequality nevertheless operates towards the segmentation of society into two clubs; a club of poor, uneducated individuals and a club of rich, educated individuals. This outcome, which may raise important social and economic concerns, has significant direct effects on aggregate economic activity and economic growth. 


\subsubsection{Skill Composition and Income Per Capita}

Income distribution affects the composition of skills in the labor force, and thus has an impact on the level of income per capita in the short-run as well as the long-run.

In the long-run the labor force consists of $\bar{l}^{u}$ young unskilled workers, $\bar{l}^{u}$ adult unskilled workers, and $\bar{l}^{s}$ skilled workers. The steady-state level of income in the economy is given therefore by (i) the wage income of unskilled individuals in the first period of life, (ii) wage and capital income of unskilled individuals in the second period of life, and (iii) wage and capital income of skilled individuals in the second period of life.

The steady-state level of income of a skilled individual in the second period of life, $I_{2}^{s}$, consists of wage income, $w^{s}$, and capital income, $\left(\bar{b}^{s}-h\right) r$, reflecting the return on saving in the first period of life. Hence, ${ }^{25}$

$$
I_{2}^{s}=w^{s}+\left(\bar{b}^{s}-h\right) r .
$$

The steady-state level of income of an unskilled individual in the second period of life, $I_{2}^{u}$, consists of a wage income, $w^{u}$, and capital income, $\left(\bar{b}^{u}+w^{u}\right) r$, reflecting the return on the saving, i.e.,

$$
I_{2}^{u}=w^{u}+\left(\bar{b}^{u}+w^{u}\right) r
$$

Finally, the income of an unskilled individual in the first period of life, $I_{1}^{u}$, consists only of the wage income, $w^{u}:^{26}$

$$
I_{1}^{u}=w^{u} .
$$

The aggregate level of income in the domestic economy in the steady-state, $\bar{Y}$, is therefore

$$
\bar{Y}=I_{2}^{s} \bar{l}^{s}+I_{2}^{u} \bar{l}^{u}+I_{1}^{u} \bar{l}^{u}
$$

Using the fact that $\bar{l}^{s}+\bar{l}^{u}=1$, it follows that

$$
\begin{aligned}
\bar{Y} & =\left[w^{u}(2+r)+r \bar{b}^{u}\right]\left(1-\bar{l}^{s}\right)+\left[w^{s}+r\left(\bar{b}^{s}-h\right)\right] \bar{l}^{s} \\
& =w^{u}(2+r)+r \bar{b}^{u}+\left[\left(w^{s}-r h\right)-w^{u}(2+r)+r\left(\bar{b}^{s}-\bar{b}^{u}\right)\right] \bar{l}^{s} .
\end{aligned}
$$

The steady-state level of income per capita is $\bar{y}=\bar{Y} / 2$, noting that the size of the population is equal to 2 in every time period.

\footnotetext{
${ }^{25}$ In the steady-state the level of intergenerational transfer among skilled dynasties exceeds the cost of education, $h$. Hence skilled individuals have a positive level of saving on which they receive the interest rate for lenders, $r$.

${ }^{26}$ Note that individuals in the first period of their lives do not have capital income. They receive an inheritance that constitutes their wealth in the first period, but this is not earned income and is thus not relevant for the calculation of an economy's aggregate income.
} 
An increase in the fraction of skilled workers increases therefore income per capita. Namely,

$$
\frac{\partial \bar{y}}{\partial \bar{l}^{s}}=\left[\left(w^{s}-r h\right)-w^{u}(2+r)+r\left(\bar{b}^{s}-\bar{b}^{u}\right)\right] / 2>0,
$$

noting that $\bar{b}^{s}>\bar{b}^{u}$ (as follows from (28)) and $\left(w^{s}-r h\right)-w^{u}(2+r)>0$ (as a result of Assumption 2.A3).

Moreover, a society characterized by a lower threshold of bequest above which individuals invest in human capital (i.e., a lower level of $g$ ) have a higher level of income per capita in the steady-state. Namely, as follows from (31) and (37),

$$
\frac{\partial \bar{y}}{\partial g}=\frac{\partial \bar{y}}{\partial \bar{l}^{s}} \frac{\partial \bar{l}^{s}}{\partial g}<0
$$

Thus the initial distribution of income affects income per capita in the short-run as well as in long-run. If the distribution of income across members of society is characterized by a lower fraction of individuals that can not invest in human capital then income per capita increases in the long-run.

For a given distribution of income, income per capita in the long-run is higher the lower is the threshold level of bequest, $g$, above which investment in human capital is beneficial for members of the dynasty in the long-run. Namely, income per capita in the long-run is higher if (a) the cost of education, $h$, is lower, (b) the wage of a skilled worker, $w^{s}$, and thus the incentive to become a skilled worker is higher, (c) the interest rate for borrowers, $i$, is lower, or (d) the propensity of individuals to bequeath, $(1-\alpha)$, is higher.

\subsection{Inequality and Economic Development}

Income distribution affects the growth process and the level of income per capita in the long-run. Inequality in the distribution of income may have an adverse effect on the growth process in a non-poor economy, whereas inequality may have a beneficial effect on the growth process in poor economies.

Consider an economy in period $t$ where income per capita is sufficiently large relative to the cost of education. In particular, suppose that the average level of bequest in period $t, \hat{b}_{t}$, exceeds the critical level, $g$, above which investment in human capital is beneficial for members of the dynasty in the long-run, i.e.,

$$
\hat{b}_{t} \equiv b_{t}^{s} l_{t}^{s}+b_{t}^{u} l_{t}^{u}>g
$$


As is illustrated in Figure 5, for a given average level of bequest in period $t, \hat{b}_{t}$, an increase in inequality (for a wide class of measures of inequality) will be associated with an increase in the number of individuals below the critical level $g$. Thus, inequality in non-poor economies is likely to reduce investment in human capital and may thus decrease the long-run level of income per capita.

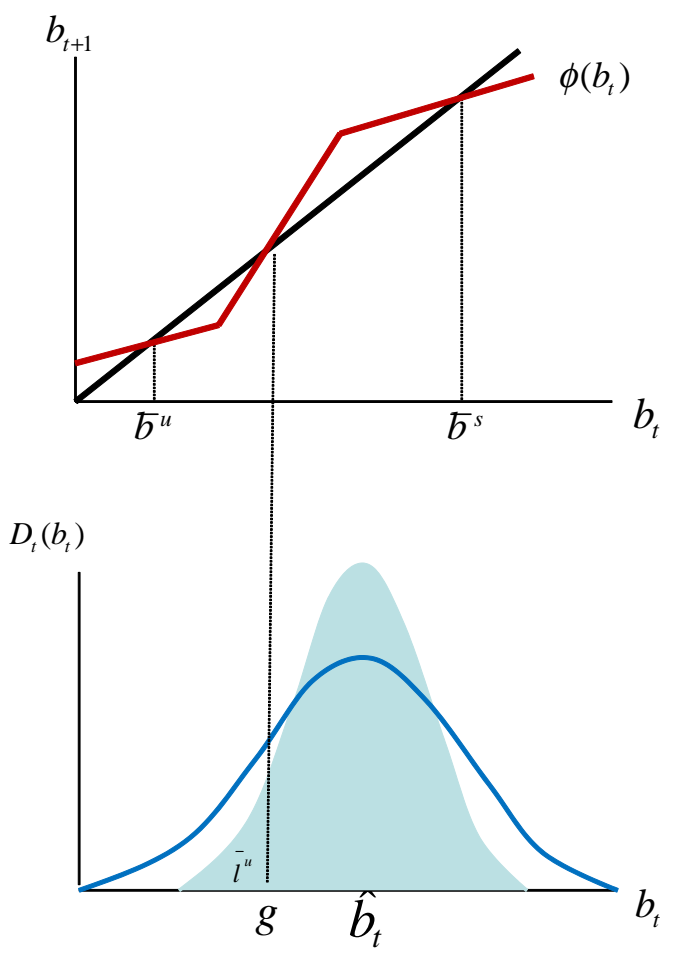

Figure 5. The Adverse Effect of Inequality on the Process of Development: A Non-Poor Economy

Consider an economy in period $t$ where income per capita is sufficiently low relative to the cost of education. In particular suppose that the average level of bequest in period $t, \hat{b}_{t}$, is lower than the critical level, $g$, above which investment in human capital is beneficial for members of the dynasty in the long-run, i.e.,

$$
\hat{b}_{t} \equiv b_{t}^{s} l_{t}^{s}+b_{t}^{u} l_{t}^{u}<g
$$

As is illustrated in Figure 6 , for a given average level of bequest in period $t, \hat{b}_{t}$, an increase in inequality (for a wide class of measures of inequality) will be associated with an increase in the number of individuals above the critical level $g$. Thus, inequality in poor economies may induce investment in human capital and may thus increase the long-run level of income per capita. 


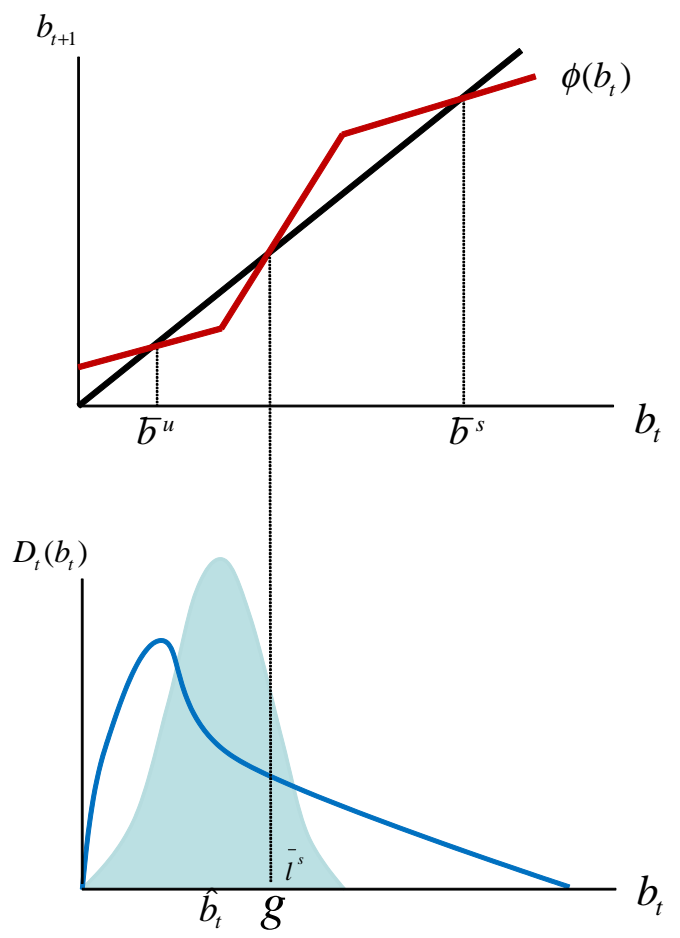

Figure 6. The Positive Effect of Inequality on the Process of Development: A Poor Economy

Thus the model generates the following testable predictions.

Proposition 1 Among economies that are identical in their structural characteristics (i.e., production technologies, preferences, the cost of education, and the degree of credit market imperfections) and therefore in the threshold level of bequest above which investment in human capital is beneficial,

a. Inequality in the distribution of income will be associated with higher income per capita across poor economies.

b. Inequality in the distribution of income will be associated with lower income per capita across non-poor economies.

\subsection{Robustness}

\subsubsection{Labor-Augmenting Technological Progress}

Suppose that the economy experiences an exogenous labor-augmenting technological progress that transforms the labor force and increases the productivity of workers in both the skilled labor-intensive and the unskilled labor-intensive sector. 
The output produced in the skilled labor-intensive sector in period $t$ is

$$
Y_{t}^{s}=F\left(K_{t}, A_{t} L_{t}^{s}\right) \equiv A_{t} L_{t}^{s} f\left(k_{t}\right) ; \quad k_{t} \equiv K_{t} / A_{t} L_{t}^{s},
$$

where $A_{t}$ is the level of technology in period $t$, and $A_{t} L_{t}^{s}$ is the number of efficiency units of skilled labor employed in production at time $t$. Similarly, the output produced at the unskilled labor-intensive sector in period $t$ is

$$
Y_{t}^{u}=A_{t} a L_{t}^{u}
$$

Technology evolves over time at a constant exogenous rate $\lambda$.

$$
A_{t+1}=(1+\lambda) A_{t}
$$

where $\lambda>0$ is the rate of labor-augmenting technological progress, and the level of technology at time $0, A_{0}$, is exogenously given.

As follows from the producer's profit maximization and the presence of perfect international capital mobility,

$$
\begin{aligned}
& w_{t}^{s}=A_{t}\left[f(k)-f^{\prime}(k) k\right] \equiv A_{t} w^{s} \\
& w_{t}^{u}=A_{t} a \equiv A_{t} w^{u} \\
& r_{t}=r .
\end{aligned}
$$

Suppose further that the acquisition of education is associated with a fixed cost, $c_{t}^{h}$, that reflects the indivisibility of human capital formation in general and of academic degrees in particular. The fixed cost of education can be viewed as a weighted average of the payments to teachers, administrators, and maintenance workers in the school system (i.e., a weighted average of the wages skilled and unskilled workers):

$$
c_{t}^{h}=\theta A_{t} w^{s}+(1-\theta) A_{t} w^{u} \equiv A_{t} h \quad \text { for some } \theta \in[0,1] .
$$

Hence, the second period wealth, $\omega_{t+1}^{u}$, of an unskilled member of generation $t$ who receive an inheritance, $b_{t}$, is

$$
\omega_{t+1}^{u}=A_{t} w^{u}(2+r+\lambda)+(1+r) b_{t} \equiv \omega^{u}\left(b_{t}, A_{t}\right),
$$

whereas the second period wealth, $\omega_{t+1}^{s}$, of a skilled member of generation $t$ who received an inheritance, $b_{t}$, is

$$
\omega_{t+1}^{s}=\omega^{s}\left(b_{t}, A_{t}\right) \equiv \begin{cases}A_{t+1} w^{s}-\left(A_{t} h-b_{t}\right)(1+i) & \text { if } \quad b_{t} \leq A_{t} h \\ A_{t+1} w^{s}+\left(b_{t}-A_{t} h\right)(1+r) & \text { if } \quad b_{t} \geq A_{t} h,\end{cases}
$$


or equivalently,

$$
\omega_{t+1}^{s}=\omega^{s}\left(b_{t}, A_{t}\right) \equiv \begin{cases}A_{t}\left[w^{s}(1+\lambda)-(1+i) h\right]+(1+i) b_{t} & \text { if } \quad b_{t} \leq A_{t} h \\ A_{t}\left[w^{s}(1+\lambda)-(1+r) h\right]+(1+r) b_{t} & \text { if } \quad b_{t} \geq A_{t} h .\end{cases}
$$

Modifying Assumptions 2.A3 and 2.A4 and assuming that

$$
\begin{aligned}
& w^{s}(1+\lambda)-(1+i) h<0 \\
& w^{u}(2+r)>\left[w^{s}-(1+i) h\right]+\lambda\left(w^{s}-w^{u}\right),
\end{aligned}
$$

it follows from (46) and (48), that there exists a level of bequest, $f_{t}$, such that

$$
\omega_{t+1}^{s}=\omega^{s}\left(f_{t}\right)=\omega_{t+1}^{u}=\omega^{u}\left(f_{t}\right)
$$

where

$$
f_{t}=\frac{A_{t}\left\{w^{u}(2+r)-\left[w^{s}-(1+i) h\right]-\lambda\left(w^{s}-w^{u}\right)\right\}}{(i-r)}=f\left(A_{t}\right) .
$$

Moreover,

$$
\frac{f_{t}}{A_{t}}=\frac{w^{u}(2+r)-\left[w^{s}-(1+i) h\right]-\lambda\left(w^{s}-w^{u}\right)}{(i-r)} \equiv \hat{f}>0 .
$$

The evolution of bequest is given therefore by

$$
b_{t+1}= \begin{cases}(1-\alpha)\left\{A_{t} w^{u}(2+r+\lambda)+(1+r) b_{t}\right\} & b_{t} \in\left[0, f_{t}\right] \\ (1-\alpha)\left\{A_{t}\left[w^{s}(1+\lambda)-(1+i) h\right]+(1+i) b_{t}\right\} & b_{t} \in\left[f_{t}, A_{t} h\right] \\ (1-\alpha)\left\{A_{t}\left[w^{s}(1+\lambda)-(1+r) h\right]+(1+r) b_{t}\right\} & b_{t} \in\left[A_{t} h, \infty\right) .\end{cases}
$$

Let $\hat{b}_{t+1} \equiv b_{t+1} / A_{t+1}$, then

$$
\hat{b}_{t+1} \equiv \psi\left(b_{t}\right)= \begin{cases}{\left[\frac{1-\alpha}{1+\lambda}\right]\left\{w^{u}(2+r+\lambda)+(1+r) \hat{b}_{t}\right\}} & \hat{b}_{t} \in[0, \hat{f}] \\ {\left[\frac{1-\alpha}{1+\lambda}\right]\left\{\left[w^{s}(1+\lambda)-(1+i) h\right]+(1+i) \hat{b}_{t}\right\}} & \hat{b}_{t} \in[\hat{f}, h] \\ {\left[\frac{1-\alpha}{1+\lambda}\right]\left\{\left[w^{s}(1+\lambda)-(1+r) h\right]+(1+r) \hat{b}_{t}\right\}} & \hat{b}_{t} \in[h, \infty) .\end{cases}
$$

Hence as long as

$$
\begin{aligned}
& (1-\alpha)(1+r)<(1+\lambda) \\
& (1-\alpha)(1+i)>(1+\lambda),
\end{aligned}
$$


$\psi(\hat{f})<\hat{f}$ and $\psi(h)>h$, the dynamical system is characterized by multiple steady states, where the unstable equilibrium is

$$
\hat{g}=\frac{(1-\alpha)\left[(1+i) h-w^{s}(1+\lambda)\right]}{[(1-\alpha)(1+i)-(1+\lambda)]}>0 .
$$

Thus, the qualitative analysis is unaffected by labor-augmenting technological progress. Moreover, if technological progress is a function of the skilled composition of the labor force, inequality would have an effect on the growth rate of the economy in the steady-state.

\subsubsection{Interactions Across Dynasties}

The basic Galor-Zeira model establishes the potential adverse effect of inequality on economic growth in an economy in which wages, for simplicity, are unaffected by the composition of the labor force. The structure of the basic model is designed to assure that factor prices are constant over time, permitting a simple characterization of the dynamics of income distribution and its implication for aggregate economic activities and economic development. However, as established in the second part of Galor and Zeira (1993), the main hypothesis is robust to the endogenization of wages and thus to the incorporation of interdependence in investment decisions across dynasties.

The robustness of the main insights of the theory in an environment where factor prices are endogenously determined and investment decisions across dynasties are interdependent is established in a large number of studies (e.g., Banerjee and Newman, 1993; Galor and Moav, 2004).

\subsubsection{Random Shocks}

The persistent effect of inequality is immune to shocks to the outcome of investment in human capital, as long as wages are endogenous. Notably, Banerjee and Newman (1993) examine the effect of inequality on a different type of occupational choice (i.e., the choice between becoming an entrepreneur or a worker, rather than the choice between becoming either a skilled or an unskilled worker). They demonstrate that if credit markets are imperfect and fixed costs are associated with entrepreneurial activities, inequality may result in an under-investment in entrepreneurial activity and may therefore be harmful for economic development. Their study establishes that as long as wages are endogenous, the main hypothesis of the credit market imperfection approach as 
a whole is robust to the introduction of random shocks to the outcome of investment (in human capital or entrepreneurial activities).

\subsubsection{Concave Production of Human Capital and Alternative Utility Functions}

The qualitative impact of income distribution is unaffected by the incorporation of a divisible, concave production function of human capital, as long as the saving rate is an increasing function of income (Moav, 2002; Galor and Moav, 2004).

Moreover, as shown in earlier versions of the Galor-Zeira model, the results are robust to alternative forms of intergenerational altruism in which the utility function is defined over the utility of the offspring rather than the level of intergenerational transfer to the offspring.

\section{A Unified Theory of Inequality and Growth}

The modern perspective on the relationship between inequality and economic development has been initially segmented. It lacked a unified hypothesis regarding the relationship between inequality and the growth process, particularly in light of the (seemingly) contrasting predictions generated by the classical approach and the modern approach. The development of a unified theory of inequality and growth that captures that changing role of inequality in the process of development has provided a needed intertemporal reconciliation between the Classical viewpoint and the modern perspective, while permitting the dominating theories within the modern perspective to be placed within a broader framework.

The theory advanced by Galor and Moav (2004) suggests that the replacement of physical capital accumulation by human capital accumulation as the prime engine of economic growth has changed the qualitative impact of inequality on the process of development. In early stages of industrialization, as physical capital accumulation was a prime source of economic growth, inequality enhanced the process of development by channeling resources towards individuals whose marginal propensity to save is higher. In later stages of development, however, as physical capital accumulated and the demand for human capital increased, human capital has become the main engine of economic growth. ${ }^{27} \mathrm{~A}$ more equal distribution of income, in the presence of credit constraints, has stimulated investment in human capital and promoted economic growth.

\footnotetext{
${ }^{27}$ The rise in the demand for skilled labor may be viewed as an outcome of: (i) capital-skill complementarity, (ii) a skill-biased technological change, or (iii) an unbiased technological acceleration, reflecting the comparative advantage of educated individuals in coping with a changing technological environment (Nelson and Phelps, 1966; Schultz, 1975; Foster and Rosenzweig, 1996).
} 
The central hypothesis of this unified approach stems from the recognition that human capital accumulation and physical capital accumulation are fundamentally asymmetric. In contrast to physical capital, human capital is inherently embodied in humans and the existence of physiological constraints subjects its accumulation at the individual level to diminishing returns. The aggregate stock of human capital would therefore be larger if its accumulation would be widely spread among individuals in society, whereas the aggregate productivity of the stock of physical capital is largely independent of the distribution of its ownership in society. This asymmetry between the accumulation of human and physical capital suggests therefore that as long as credit constraints are largely binding, a more equal distribution of income is conducive for human capital accumulation, whereas, provided that the marginal propensity to save increases with income, inequality is conducive for physical capital accumulation.

The theory, therefore, provides a reconciliation between conflicting viewpoints about the effect of inequality on economic growth. It suggests that the Classical viewpoint, regarding the positive effect of inequality on the process of development, reflects the state of the world in early stages of industrialization, when physical capital accumulation is the prime engine of economic growth. In contrast, the central hypothesis of the credit market imperfection approach, regarding the negative effect of inequality on economic growth, reflects later stages of development when human capital accumulation is the prime engine of economic growth and credit constraints are largely binding.

In early stages of industrialization physical capital is scarce, the rate of return to human capital is lower than the rate of return to physical capital and the process of development is fueled by capital accumulation. The positive effect of inequality on aggregate saving dominates therefore the negative effect on investment in human capital and inequality raises aggregate savings and capital accumulation and enhances the process of development. In later stages of development, as physical capital accumulates, the complementarity between capital and skills increases the rate of return to human capital. Investment in human capital accumulation increases and the accumulation of human capital as well as physical capital fuels the process of development. Since human capital is embodied in individuals and individuals' investment in human capital is subjected to diminishing marginal returns, the aggregate return to investment in human capital is maximized if investment in human capital is widely spread among individuals in society. Equality alleviates the adverse effect of credit constraints, and has therefore a positive effect on the aggregate level 
of human capital and economic growth. Moreover, the differences in the marginal propensities to save across individuals narrow as wages increase, and the negative effect of equality on aggregate saving subsides. In later stages of development, therefore, as long as credit constraints are sufficiently binding, the positive effect of inequality on aggregate saving is dominated by the negative effect on investment in human capital, and equality stimulates economic growth. As wages further increase, however, credit constraints become less binding, differences in the marginal propensity to save further decline, and the aggregate effect of income distribution on the growth process becomes less significant. ${ }^{28}$

Although the replacement of physical capital accumulation by human capital accumulation as a prime engine of economic growth in currently developed economies is instrumental for the understanding of the role of inequality in the process of development of these advanced economies, this unified theory generates an insight about the role of inequality in the growth process of less developed economies as well. The presence of international capital inflows has diminished the role of inequality in stimulating physical capital accumulation in less developed economies. Moreover, the adoption of skill-biased technologies by some of these economies has increased the return to human capital and has strengthened the positive effect of a more equal distribution of income on human capital formation and economic growth.

The unified theory of inequality and growth may provide greatly needed theoretical guidance for empirical research in this field. In contrast to the credit market imperfection approach, which suggests that the effect of inequality depends on the country's level of income (i.e., inequality is beneficial for poor economies and harmful for others), the unified theory of inequality and growth suggests that the effect of inequality on growth depends on the relative return to physical and human capital. In economies in which the return to human capital is relatively lower, inequality is beneficial for economic growth, whereas in economies in which the return to human capital is relatively higher and credit constraints are largely binding, equality is beneficial for the development process.

\footnotetext{
${ }^{28}$ Inequality may widen once again due to skilled- or ability-biased technological change induced by human capital accumulation. This line of research was explored theoretically by Galor and Tsiddon (1997b), Acemoglu (1998), Caselli (1999), Galor and Moav (2000), among others. It is consistent with recent evidence provided by Berman et al. (1998), Goldin and Katz (1998) and Autor et al. (2008), among others.
} 


\section{Non-Financial Hurdles for Human Capital Accumulation}

While the process of industrialization raised the importance of human capital in the production process, reflecting its complementarity with physical capital and technology, human capital accumulation has not benefited all sectors of the economy. Inequality in the ownership of factors of production has generated an incentive for some better-endowed agents to block the implementation of institutional changes and policies that promote human capital formation, resulting in a suboptimal level of investment in human capital from a growth perspective. In particular, variation in the distribution of ownership over land and other natural resources across countries has contributed to the observed disparity in human capital formation and to the divergent development patterns across the globe.

\subsection{Concentration of Landownership}

The transition from an agricultural to an industrial economy changed the nature of the main economic conflict in society. Unlike the agrarian economy, which was characterized by a conflict of interests between the landed aristocracy and the masses, the process of industrialization has brought about an additional conflict between the entrenched landed elite and the emerging capitalist elite. In light of a lower degree of complementarity between human capital and the agricultural sector, education has increased the productivity of labor in industrial production more than in agricultural and primary good production, inducing rural-to-urban migration and thus a decline in the return to landowners. Thus, while industrialists have had a direct economic incentive to support education policies that would foster human capital formation (Galor and Moav, 2006), landowners, whose interests lay in the reduction of the mobility of their labor force, have favored policies that deprived the masses of education (Galor et al., 2009). ${ }^{29}$

The adverse effect of the implementation of public education on landowners' income from agricultural production has been magnified by the concentration of land ownership. Thus, as

\footnotetext{
${ }^{29}$ In accordance with the unified approach for the study of inequality and economic development, this line of research suggests that capital accumulation in the process of industrialization gradually intensified the relative scarcity of skilled labor and generated an incentive for human capital accumulation. Investment in human capital, however, has been sub-optimal due to credit market imperfections, and public investment in education has been therefore growth-enhancing. Due to the complementarity between physical and human capital in production, the capitalists were among the prime beneficiaries of the accumulation of human capital by the masses. They therefore had the incentive to support the provision of public education that improved their economic well-being and contributed significantly to the demise of the capitalists-workers class structure and to changes in the nature of inequality in society that were conducive to economic development. Mutually beneficial reforms are also considered by Lizzeri and Persico (2004) and Doepke and Zilibotti (2005).
} 
long as landowners affected the political process and thereby the implementation of growthenhancing education policies, inequality in the distribution of land ownership has been a hurdle for human capital accumulation, slowing the process of industrialization and the transition to modern growth. ${ }^{30}$

Economies in which land and other natural resources have been more equally distributed have implemented earlier public education campaigns and have benefited from the emergence of a skill-intensive industrial sector and a rapid process of development. In contrast, among economies marked by a more unequal distribution of ownership over land and other natural resources, resource abundance that was a source of richness in the early stages of development has led in later stages to under-investment in human capital, an unskilled labor-intensive industrial sector, and a slower growth process. Thus, variation in the distribution of ownership over land and other natural resources across countries has contributed to disparity in human capital formation and the industrial composition of the economy, and thus to divergent development patterns across the globe. ${ }^{31}$

An alternative mechanism that underlines the adverse effect of inequality on human capital formation and economic development has been advanced by Engerman and Sokoloff (2000) and Acemoglu et al. (2005). They argued and provided evidence that geographical conditions that led to income inequality brought about oppressive institutions (e.g., restricted access to the democratic process and to education) designed to maintain the political power of the elite and to preserve the existing inequality between the elite and the masses. ${ }^{32}$ Thus, Engerman and Sokoloff (2000) underlined the role of the sustained conflict between the elite and the masses in the delay in the implementation of growth-enhancing educational policies and thus in the adverse effect of inequality on the process of development, suggesting the perpetual desirability of extractive

\footnotetext{
${ }^{30}$ Interestingly, during the 19th century, the emergence of a broad-based demand for human capital-intensive services by the landowners in land-rich economies in Latin America (e.g., Argentina) triggered the establishment of an extensive public education system prior to the onset of significant manufacturing activities (Galiani et al., 2008). Thus, lack of concentration of land ownership (that was conducive for a broad-based demand for human capital-intensive services by the landowners) had a positive effect on human capital formation even prior to industrialization.

${ }^{31}$ Rajan (2009) reinforces this thesis, suggesting that rent preservation and its interaction with inequality in ownership over factor endowment is a recipe for paralysis and poverty.

${ }^{32}$ Acemoglu et al. (2005) maintain that economic performance across countries have a colonial origin, reflecting the institutional quality that were introduced by European colonialism across the globe. They have argued that historical reversals in the economic performance of societies have a colonial legacy that reflects the imposition of extractive institutions by European colonizers in affluent regions that benefited from favorable geographical conditions in the pre-colonial era and the implementation of growth-enhancing institutions in poorer regions.
} 
institutions for the ruling elite in the absence of changes in the political structure. ${ }^{33}$

\subsection{Social-Political Transitions}

Inequality and its association with sociopolitical instability have been identified as an additional adverse force in the process of development. In particular, the effect of inequality on social conflict and on political and educational reforms was examined by Alesina and Perotti (1996), Acemoglu and Robinson (2000), Bourguignon and Verdier (2000), and Gradstein (2007). ${ }^{34}$ These studies suggest that reforms and redistribution from the elite to the masses diminish the tendency for sociopolitical instability and may therefore stimulate investment and economic growth. In particular, Acemoglu and Robinson (2000) argue that the extension of the franchise during the nineteenth century can be viewed as a commitment device to ensure future income redistribution from the elite to the masses. ${ }^{35}$

In contrast, Galor and Moav (2006) have argued that the transformation in class structure and inequality can be viewed as a byproduct of a productive cooperation between capitalists and workers, rather than an outcome of a divisive class struggle. In accordance with the unified approach for the study of inequality and economic development, this line of research suggests that capital accumulation in the process of industrialization gradually intensified the relative scarcity of skilled labor and generated an incentive for human capital accumulation. Investment in human capital, however, has been sub-optimal due to credit market imperfections, and public investment in education has been therefore growth-enhancing, as per Galor and Zeira (1993). Due to the complementarity between physical and human capital in production, the capitalists were among the prime beneficiaries of the accumulation of human capital by the masses. They therefore had the incentive to support the provision of public education that improved their economic wellbeing and contributed significantly to the demise of the capitalists-workers class structure and to changes in the nature of inequality in society that were conducive to economic development.

\footnotetext{
${ }^{33}$ In contrast, Galor et al. (2009) demonstrate that even if the political structure in the economy remains unchanged, economic development and a gradual diversification of the assets held by the landed aristocracy may ultimately trigger the implementation of growth-promoting institutions once the stake of the landed aristocracy in the efficient operation of the industrial sector dominates their overall economic interest.

${ }^{34}$ See also Bowles and Gintis (1975).

${ }^{35}$ Mejía and Posada (2007) identify conditions under which a social conflict lead to the transition to democracy and those under which purely economic forces lead to the transition, underlying the relative role of inequality, the importance of a human capital externalities in production, and the feasibility of redistribution by the masses.
} 


\subsection{Gender Inequality}

The decline in gender inequality, which was brought about by the rise in the demand for human capital in the process of development, reinforced the positive association between a more egalitarian distribution of income and economic growth. The decline in gender inequality contributed to the onset of the demographic transition as well as to the rise in female labor force participation, fostering the growth process as a whole. The decline in the gender wage gap has affected household fertility decisions, female labor force participation and thus the growth process.

As suggested by Galor and Weil, $(1996,1999)$ technological progress and capital accumulation complemented mentally intensive tasks and substituted for physically intensive tasks in industrial production. In light of the comparative physiological advantage of men in physically intensive tasks and of women in mentally intensive tasks, the demand for women's labor input gradually increased, inducing a decline in fertility rates, a significant increase in labor force participation, and a transition from stagnation to growth. ${ }^{36}$

\section{Evidence}

\subsection{Inequality, Human Capital Formation and Economic Growth}

Several attempts have been made to examine the theoretical predictions of the credit market imperfections approach and the political economy approach about the effect of inequality and heterogeneity on economic growth. Consistent with the hypothesis advanced by the theories, early cross-country analyses by Alesina and Rodrik (1994), Persson and Tabellini (1994) and Perotti (1996) have established a negative association between the level of inequality and economic growth.

Importantly, Perotti (1996) conducted an examination of the various channels through which inequality may affect economic growth, as proposed by the modern theoretical perspective. His study provides support for the validity of the human capital formation channel, showing that inequality is indeed associated with lower level of human capital formation, and lower human capital formation is associated with lower levels of economic growth. ${ }^{37}$ Further support for the

\footnotetext{
${ }^{36}$ The decline in the overall level of inequality that was associated with the emergence of human capital has been linked theoretically, empirically and quantitatively to the reduction in fertility and therefore in light of the quantity-quality trade-off (e.g., Rosenzweig and Wolpin, 1980; Hanushek, 1992) to lower levels of investment in human capital and income. See, Galor and Zang (1997), Dahan and Tsiddon (1998), Kremer and Chen (2002), de la Croix and Doepke (2003), and Moav (2005).

${ }^{37}$ In line with related theoretical arguments that human capital formation and fertility are negatively related and
} 
main predictions of the education channel, advanced in the context of the credit market imperfection approach, has been generated by Deininger and Squire (1998). Utilizing the distribution of land as a proxy for the distribution of assets, they find that initial inequality has a significant adverse effect on education and economic growth. Moreover, consistent with the predictions of credit market imperfections approach that imperfection ought to have a larger effect on the investment decisions of individuals with lower income, they find that initial inequality primarily hurts the poor. ${ }^{38}$

In contrast to the human capital channel, Perotti's examination of the political economy channel was not favorable to the theories advanced by Alesina and Rodrik (1994) and Persson and Tabellini (1994). His findings refute this early hypothesis of the political economy approach, demonstrating that in contrast to their proposed channel, inequality is in fact associated with lower levels of taxation, while lower levels of taxation, contrary to the theories, are associated with lower levels of economic growth.

Later studies have deviated from the desirable examination of the channels through which inequality may affect growth, and restricted their attention to the reduced form relationship between inequality and growth. Notably, Forbes (2000) and Barro (2000) examined the effect of inequality on economic growth in a panel of countries. They find a positive and zero effect, respectively, of an increase in inequality on economic growth.

These findings, however, ought to be interpreted very cautiously. They appear to have no bearing on the validity of the theories and are not very informative about the overall effect of inequality. First, these studies examine the effect of inequality beyond its effects through education, fertility, and investment. For instance, Barro (2000) has found that, once controls for education, fertility, and investment are introduced, there is no relationship between inequality and economic growth in the entire sample. His findings, therefore, suggest that inequality does not have a direct effect on growth beyond its effects through education, fertility and investment (i.e., the dominating channels through which inequality operates), implying perhaps that the dominating channels through which inequality operates are those proposed in the literature. In particular, if the control for fertility is dropped in Barro (2000), the effect of inequality on growth

thus inequality would be expected to have contrasting effects on these two variables (e.g., Galor and Zhang, 1997), Perotti (1996) suggests that the human capital channel is reinforced by the introduction of fertility. Inequality is associated with higher fertility rates and a lower level of investment in human capital, which are in turn associated with lower economic growth.

${ }^{38}$ The adverse effects of financial constraints on economic development are well established (Levine, 2005). 
is significantly negative, as predicted by the theory. Moreover, these studies examine the effect of inequality in the short run (i.e., the effect of inequality on the average growth rate in the subsequent 5-10 years), while as suggested by the theories, inequality is likely to have mostly longer-run effects (e.g., via the formation of human capital).

Moreover, even within the context of the limited scope of the studies of Forbes (2000) and Barro (2000), their econometric methodology and their findings have been challenged. Banerjee and Duflo (2003) argued that the linear regression structure imposed in these and earlier empirical studies is inconsistent with the predictions of the theories and the qualitative findings may be an artifact of the imposed linearity. They find that changes in inequality (in any direction) are associated with lower growth rates. Moreover, in line with the adverse long-run impact of inequality proposed by the theories, they find a negative relationship between growth rates and lagged inequality.

Recently, Easterly (2007) has reaffirmed the hypothesis advanced by the modern theories that inequality has an adverse effect on human capital formation and economic development. Using agricultural endowments as an instrument for inequality in order to overcome concerns about measurement errors and the endogeneity of inequality, his cross-country analysis suggests that inequality has been a barrier to schooling and economic prosperity.

\subsection{Industrialization and Human Capital Formation}

The process of industrialization was characterized by a gradual increase in the relative importance of human capital in the production process. As underlined by Unified Growth Theory (Galor, 2011), this important development was triggered by acceleration in the rate of technological progress and the role of human capital in adapting to a rapidly changing technological environment.

In the first phase of the Industrial Revolution, human capital played a limited role in the production process. Education was motivated by a variety of factors, including religion, enlightenment, social control, moral conformity, sociopolitical stability (i.e., the shadow of rebellion of the masses), social and national cohesion, and military efficiency. The extent to which public education was provided was not correlated with industrial development, and it differed across countries due to political, cultural, social, historical, and institutional factors. Human capital had a limited role in the production process; education instead served religious, social, and na- 
tional goals. As argued by Landes (1969), although certain workers - supervisory and office personnel in particular - were required to be able to read and do the elementary arithmetical operations in order to perform their duties, a large fraction of the work of industry was performed by illiterates, especially in the early days of the Industrial Revolution.

In contrast, during the second phase of the Industrial Revolution, the demand for skilled labor in the growing industrial sector markedly increased. Human capital formation was designed primarily to satisfy the increasing skill requirements in the process of industrialization, and industrialists became involved in shaping the educational system. Moreover, the reversal of the Malthusian relationship between income and population growth during the demographic transition corresponded to a further increase in the level of resources invested in each child.

Evidence relating to the evolution of the return on human capital during this period is scarce and controversial. ${ }^{39}$ One can mistakenly argue that the lack of clear evidence about the increase in the return on human capital during this period indicates the absence of a significant increase in the demand for human capital. However, this partial equilibrium argument is flawed. The return on human capital is affected by the demand and supply of human capital. Technological progress in the second phase of the Industrial Revolution brought about an increase in demand for human capital, and indeed, in the absence of a supply response, one would have expected an increase in the return on human capital. However, the significant increase in schooling that took place during the nineteenth century (in particular, the introduction of public education), which lowered the cost of education, generated a significant increase in the supply of educated workers. Some of this supply response was a direct reaction to the increase in demand for human capital and thus may have only operated to partially offset the increase in the return on human capital. However, the removal of the adverse effect of credit constraints on the acquisition of human capital (as reflected by the introduction of public education) generated an additional force that increased the supply of educated labor and operated to reduce the return on human capital.

Reassuringly, Becker et al. (2011), in the first rigorous attempt to examine empirically the role of education in the process of industrialization, provide evidence about the important role that education played in the process of industrialization. Using variation in pre-industrial education across counties in Prussia in 1816 as instrument for later education levels in these

\footnotetext{
${ }^{39}$ Not surprisingly, existing evidence focusing on the return on old skills (e.g., construction) does not find that the return on such skills increased in England over the course of the nineteenth century (Clark, 2005).
} 
counties, they find that education contributed significantly to industrialization in two industrial phases, in 1849 and 1882. Moreover, as implied by Unified Growth Theory, the find that the role of education have been intensified in the second phase of Prussia's industrialization. ${ }^{40}$

\subsubsection{Industrial Demand for Education}

Education reforms in developed countries in the eighteenth and nineteenth centuries are indicative of the significance of industrial development in the formation of human capital during the second half of the nineteenth century. In particular, differences in the timing of the establishment of a national system of public education between England and continental Europe are instrumental in isolating the role that industrial forces played in human capital formation.

England During the first phase of the Industrial Revolution (1760-1830), capital accumulation increased significantly without a corresponding increase in the supply of skilled labor. The investment-output ratio increased from 6\% in 1760 to $12 \%$ in 1831 (Crafts, 1985, p. 73), whereas literacy rates remained largely unchanged, and the state devoted virtually no resources to raising the level of literacy among the masses (Mokyr, 2001). Literacy was largely a cultural skill or a hierarchical symbol and was of limited use in the production process. For instance, in 1841 , only $5 \%$ of male workers and only $2 \%$ of female workers were employed in occupations in which literacy was strictly required (Mitch, 1992). Furthermore, an illiterate labor force could operate the existing technology, and economic growth was not impeded by educational retardation. ${ }^{41}$ Workers developed skills primarily through on-the-job training, and child labor was highly valuable.

The development of a national public system of education in England lagged behind other Western European countries by nearly half a century (Sanderson, 1995). ${ }^{42}$ England's early industrialization occurred without direct state intervention in the development of the minimal skills

\footnotetext{
${ }^{40}$ The rise in the demand for education in the process of industrialization (prior to the demographic transition) is underlined in the theories of Galor and Weil (2000) and Galor and Moav (2002). Moreover, the contribution of education to industrialization is consistent with both theories, although Galor and Moav (2002) attributes a more significant role for education in the first phase of industrialization.

${ }^{41}$ Some have argued that the low skill requirements even declined over this period. For instance, Sanderson (1995) suggests that the emerging economy created a whole range of new occupations that required even less literacy and education than the old ones.

${ }^{42}$ For instance, in his parliamentary speech in defense of his 1837 education bill, Whig politician Henry Brougham reflected on this gap: "It cannot be doubted that some legislative effort must at length be made to remove from this country the opprobrium of having done less for education of the people than any of the more civilized nations on earth" (Green, 1990, pp. 10-11).
} 
required for industrial production (Green, 1990). England initiated a sequence of reforms in its educational system after the 1830s and literacy rates gradually increased. The process was initially motivated by nonindustrial reasons, such as religion, social control, moral conformity, enlightenment, and military efficiency, as was the case in other European countries (e.g., Germany, France, Holland, and Switzerland) that had supported public education much earlier. However, in light of the modest demand for skills and literacy by the capitalists, the level of governmental support was rather small. ${ }^{43}$

As the Industrial Revolution progressed to its second phase, the demand for skilled labor in the growing industrial sector markedly increased, and the proportion of children aged 5-14 in primary schools rose from $11 \%$ in 1855 to $25 \%$ in 1870 (Flora et al., 1983). Literacy became an increasingly desirable characteristic for employment, as indicated by job advertisements of the period (Mitch, 1993). In light of industrial competition from other countries, capitalists started to recognize the importance of technical education for the provision of skilled workers. As noted by Sanderson (1995, pp. 10-13), "Reading ... enabled the efficient functioning of an urban industrial society laced with letter writing, drawing up wills, apprenticeship indentures, passing bills of exchange, and notice and advertisement reading." Moreover, manufacturers argued that "universal education is required in order to select, from the mass of the workers, those who respond well to schooling and would make a good foreman on the shop floor" (Simon, 1987, p. 104).

As it became apparent that skills were necessary for the creation of an industrial society, replacing previous concerns that the acquisition of literacy would make the working classes receptive to radical and subversive ideas, capitalists lobbied for the provision of public education. ${ }^{44}$ The pure laissez-faire policy failed to develop a proper educational system, and capitalists demanded government intervention in the provision of education. As Leeds iron-master and advocate of technical education James Kitson explained to the Select Committee on Scientific Instruction (1867-1868): "[T] $[$ he question is so extensive that individual manufacturers are not able to grapple with it, and if they went to immense trouble to establish schools they would be doing it in

\footnotetext{
${ }^{43}$ Even in 1869, the English government funded only one-third of school expenditure (Green, 1990).

${ }^{44}$ There was a growing consensus among workers and capitalists about the virtues of reform. The labor union movement was increasingly calling for a national system of nonsectarian education. The National Education League (founded in 1869 by radical Liberals and Dissenters) demanded a free, compulsory, nonsectarian national system of education (Green, 1990).
} 
order that others may reap the benefit" (Green, 1990, p. 295). ${ }^{45}$ An additional turning point in the attitude of English capitalists toward public education was the Paris Exhibition of 1867, where the limitations of English scientific and technical education became evident. Unlike the 1851 exhibition in which England won most of the prizes, the English performance in Paris was rather poor, and of the 90 classes of manufacturers, Britain dominated only in $10{ }^{46}$

In 1868, the government established the parliamentary Select Committee on Scientific Education. This was the origin of nearly 20 years of various parliamentary investigations into the relationship between the sciences, industry, and education designed to address the capitalists' outcry over the necessity of universal public education. A sequence of reports by the Committee in 1868, by the Royal Commission on Scientific Instruction and the Advancement of Science during 1872-1875, and by the Royal Commission on Technical Education in 1882 underlined the inadequate training for supervisors, managers, proprietors and workers. They argued that most managers and proprietors did not understand the manufacturing process and thus failed to promote efficiency, investigate innovative techniques or value the skills of their workers (Green, 1990). In particular, W. E. Forster, the vice president of the committee of the Council of Education, told The House of Commons: "Upon the speedy provision of elementary education depends our industrial prosperity . . . if we leave our work-folk any longer unskilled ... they will become overmatched in the competition of the world" (Hurt, 1971, pp. 223-224). The reports made various recommendations that highlighted the need to redefine elementary schools, to revise the curriculum throughout the entire school system (particularly with respect to industry and manufacturing) and to improve teacher training.

In addition, in 1868 the Schools Inquiry Commission investigated the secondary schools. It found that the level of instruction in the vast majority of schools was very unsatisfactory, reflecting the employment of untrained teachers and the use of antiquated teaching methods. Its main proposal was to organize a state inspection of secondary schools and provide efficient education geared to the specific needs of its consumers. In particular, the Royal Commission on Technical Education of 1882 confirmed that England was being overtaken by the industrial superiority

\footnotetext{
${ }^{45}$ Indeed, the Factory Act of 1802 required owners of textile mills to provide elementary instruction for their apprentices, but the law was poorly enforced (Cameron, 1993).

${ }^{46}$ Lyon Playfair, who was one of the jurors, reported that "a singular accordance of opinion prevailed that our country has shown little inventiveness and made little progress in the peaceful arts of industry since 1862." The cause of this lack of progress "upon which there was most unanimity conviction is that France, Prussia, Austria, Belgium and Switzerland possess good systems of industrial education and that England possesses none" (Green, 1990, p. 296).
} 
of Prussia, France and the United States and recommended the introduction of technical and scientific education to secondary schools.

It appears that the English government gradually yielded to the capitalists and increased contributions to elementary as well as higher education. In the 1870 Education Act, the government assumed responsibility for ensuring universal elementary education. In 1880, prior to the significant extension of the franchise in 1884 - which made the working class the majority in most industrial counties - education was made compulsory throughout England. The 1889 Technical Instruction Act allowed the new local councils to set up technical instruction committees, and the 1890 Local Taxation Act provided public funds that could be spent on technical education (Green, 1990). Finally, the 1902 Balfour Education Act marked the establishment of a national education system that provided free compulsory elementary education (Ringer, 1979; Green, 1990).

School enrollment of 10 -year-olds increased from $40 \%$ in 1870 to $100 \%$ in 1900 . The literacy rate among men, which was stable at around $65 \%$ during the first phase of the Industrial Revolution, increased significantly during the second phase reaching nearly $100 \%$ at the end of the nineteenth century (Cipolla, 1969). Also, the proportion of children aged 5-14 in primary schools increased significantly in the second half of the nineteenth century, from $11 \%$ in 1855 to $74 \%$ in 1900 (Flora et al., 1983).

Continental Europe The early development of public education occurred in the western countries of continental Europe (e.g., Prussia, France, Sweden, and the Netherlands) well before the Industrial Revolution and was motivated by social, religious, political, and national factors. However, as was the case in England, massive educational reforms occurred in the second half of the nineteenth century due to the rising demand for skills in the process of industrialization. As noted by Green (1990, pp. 293-294), "In continental Europe industrialization occurred under the tutelage of the state and began its accelerated development later when techniques were already becoming more scientific; technical and scientific education had been vigorously promoted from the center as an essential adjunct of economic growth and one that was recognized to be indispensable for countries which wished to close Britain's industrial lead."

In France the initial development of the education system occurred well before the Industrial Revolution, but the process was intensified and transformed to satisfy industrial needs 
during the second phase of industrialization. The early development of elementary and secondary education in the seventeenth and eighteenth centuries was dominated by the church and religious orders. Some state interventions in technical and vocational training were designed to reinforce development in commerce, manufacturing, and military efficiency. After the French Revolution, the state established universal primary schools, but enrollment rates remained rather low. The state concentrated on the development of secondary and higher education, with the objective of producing an effective elite to operate the military and governmental apparatus. Secondary education remained highly selective, offering general and technical instruction largely to the middle class (Green, 1990). Legislative proposals during the National Convention quoted by Cubberley (1991) are revealing about the underlying motives behind education in this period: "[C]hildren of all classes were to receive education, physical, moral and intellectual, best adapted to develop in them republican manners, patriotism, and the love of labor . . . They are to be taken into the fields and workshops where they may see agricultural and mechanical operations going on."

The process of industrialization in France, the associated increase in the demand for skilled labor, and the breakdown of the traditional apprenticeship system significantly affected the state's attitude toward education. State grants for primary schools gradually increased in the 1830s, and some legislation was introduced to provide primary education in all regions, extend higher education, and provide teacher training and school inspections. The number of communities without schools fell by $50 \%$ from 1837 to 1850 and, as the influence of industrialists on the structure of education intensified, education became more stratified according to occupational patterns (Anderson, 1975). This legislation reflected the increasing need for skilled labor in the economic environment of the period (Green, 1990). The eagerness of capitalists for rapid education reforms was reflected by the organization of industrial societies that financed schools specializing in chemistry, design, mechanical weaving, spinning, and commerce (Anderson, 1975).

As was the case in England, competition led industrialists to lobby for the provision of public education. The Great Exhibition of 1851 and the London Exhibition of 1862 created the impression that the technological gap between France and other European nations was narrowing and that French manufacturers should invest in the education of their labor force to maintain their technological superiority. Subsequently, reports on the state of industrial education by commissions established in 1862-1865 reflected the pleas of industrialists for the provision of industrial education on a large scale and for the implementation of scientific knowledge in the 
industry. "The goal of modern education . . . can no longer be to form men of letters, idle admirers of the past, but men of science, builders of the present, initiators of the future." 47 Education reforms in France were extensive in the second phase of the Industrial Revolution, and by 1881 a universal, free, compulsory, and secular primary school system had been established, and technical and scientific education was further emphasized. Illiteracy rates among conscripts tested at the age of 20 declined gradually from $38 \%$ in 1851-1855 to $17 \%$ in 1876-1880 (Anderson, 1975), and the proportion of children aged 5-14 in primary schools increased from $52 \%$ in 1850 to $86 \%$ in 1901 (Flora et al., 1983).

In Prussia, as in France, where the initial steps toward compulsory education took place at the beginning of the eighteenth century, well before the Industrial Revolution, education was viewed primarily as a way to unify the state. In the second part of the eighteenth century, education was made compulsory for all children aged 5-13. Nevertheless, these regulations were not strictly enforced partly due to the lack of funding (reflecting the difficulty of taxing landlords for this purpose) and partly due to their adverse effect on child labor income. At the beginning of the nineteenth century, motivated by the need for national cohesion, military efficiency, and trained bureaucrats, the education system was further reformed. Provincial and district school boards were established, education became compulsory (and secular) for a 3-year period, and the gymnasium was reconstituted as a state institution that provided 9 years of education for the elite (Cubberley, 1991; Green, 1990).

Similarly to England and France, industrialization in Prussia triggered the implementation of universal elementary schooling. Taxes were imposed to finance the school system, and teachers' training and certifications were established. Secondary schools started to serve industrial needs as well; the Realschulen - which emphasized the teaching of mathematics and science were gradually adopted, and vocational and trade schools were founded. Total enrollment in secondary school increased sixfold from 1870 to 1911 (Flora et al., 1983). Furthermore, the Industrial Revolution significantly affected the nature of education in German universities. German industrialists, who perceived advanced technology as a competitive advantage, lobbied for reforms in the operation of universities and offered to pay to reshape their activities toward technological training and industrial applications of basic research (McClelland, 1980).

The evolution of education in the Netherlands also reflected the interest of capitalists in

\footnotetext{
${ }^{47}$ L'enseignement Professionnel, ii (1864, p. 332), quoted in Anderson (1975, p. 194).
} 
the skill formation of the masses. In particular, as early as the 1830 s, industrial schools were established and funded by private organizations, representing industrialists and entrepreneurs. Ultimately, in the latter part of the nineteenth century, the state - urged by industrialists and entrepreneurs - started to support these schools (Wolthuis, 1999).

United States The process of industrialization in the United States also increased the importance of human capital in the production process. Evidence provided by Abramovitz and David (2000) and Goldin and Katz (2001) suggests that during 1890-1999 the contribution of human capital accumulation to the growth process of the United States nearly doubled. ${ }^{48}$ As argued by Goldin (1998), the rise of the industrial, business and commerce sectors in the late nineteenth and early twentieth centuries increased the demand for managers, clerical workers, and educated sales personnel who were trained in accounting, typing, shorthand, algebra, and commerce. Furthermore, in the late 1910s, technologically advanced industries demanded blue-collar craft workers who were trained in geometry, algebra, chemistry, mechanical drawing and related skills. The structure of education was transformed in response to industrial development and the increasing importance of human capital in the production process, and American high schools adapted to the needs of the modern workplace of the early twentieth century. Total enrollment in public secondary schools increased seventy-fold from 1870 to 1950 (Kurian, 1994). ${ }^{49}$

\subsubsection{Land Concentration: A Hurdle for Human Capital Formation}

The transition from an agricultural to an industrial economy altered the nature of the conflict among interest groups in society. The conflict of interest between the elite and the masses which had characterized the agricultural stage of development was transformed into a conflict between

\footnotetext{
${ }^{48}$ Literacy rates in the United States were rather high prior to this increase in the demand for skilled labor. Literacy rates among the white population were already $89 \%$ in 1870, 92\% in 1890, and 95\% in 1910 (Engerman and Sokoloff, 2000). Education in earlier periods was motivated by social control, moral conformity, and social and national cohesion, as well as by skills required for trade and commerce. In particular, Bowles and Gintis (1975) and Field (1976) argue that educational reforms are designed to sustain the existing social order by displacing social problems into the school system.

${ }^{49}$ As noted by Galor and Moav (2006), due to differences in the structure of education finance in the United States in comparison to European countries, capitalists in the United States had only limited incentives to lobby for the provision of education and to support it financially. Unlike the central role that government funding played in the provision of public education in European countries, the evolution of the educational system in the United States was based on local initiatives and funding. The local nature of education initiatives induced community members, in urban as well as rural areas, to play a significant role in advancing their schooling systems. American capitalists, however, faced limited incentives to support the provision of education within a county in an environment where labor was mobile across counties and the benefits from educational expenditure in one county could be reaped by employers in other counties.
} 
the entrenched landed elites and emerging capitalist elites. As documented in section 5.2.1, the capitalists who were striving for an educated labor force supported policies that promoted public education. In contrast, as documented in this section, landowners, whose interest lay in the reduction of the mobility of the rural labor force, favored policies that deprived the masses of education (Galor et al., 2009). ${ }^{50}$

Anecdotal evidence suggests that the degree of concentration of land ownership across countries and regions is inversely related to education expenditure and attainment. North and South America provide the most distinctive set of suggestive evidence regarding the relationship among the distribution of land ownership, education reforms, and the process of development. The original colonies in North and South America had vast amounts of land per person and levels of income per capita that were comparable to those of Western Europe. North and Latin America, however, differed in the distribution of land and resources. While the United States and Canada have been characterized by a relatively egalitarian distribution of land ownership, in the rest of the New World, land and resources have been persistently concentrated in the hands of the elite (Deininger and Squire, 1998).

Persistent differences in the distribution of land ownership between North and Latin America were associated with a significant divergence in education and income levels across these regions (Maddison, 2001). Although all economies in the Western hemisphere were developed enough in the early nineteenth century to justify investment in primary schools, only the United States and Canada were engaged in the education of the general population (Coatsworth, 1993; Engerman and Sokoloff, 2000). ${ }^{51}$

Variations in the degree of inequality in the distribution of land ownership among Latin American countries were reflected in differences in investment in human capital as well. In particular, Argentina, Chile, and Uruguay, in which inequality in the distribution of land ownership was less pronounced, invested significantly more in education (Engerman and Sokoloff, 2000). Similarly, Nugent and Robinson (2002) show that in Costa Rica and Colombia, where coffee is typically grown on small farms (reflecting lower inequality in the distribution of land), income

\footnotetext{
${ }^{50}$ Interestingly, during the 19th century, the emergence of a broad-based demand for human capital-intensive services by the landowners in land-rich economies in Latin America (e.g., Argentina) triggered the establishment of an extensive public education system prior to the onset of significant manufacturing activities (Galiani et al., 2008).

${ }^{51}$ One may view the conflict that led to the Civil War in the United States as a struggle between the industrialists in the North, who were striving for a large supply of (educated) workers, and the landowners in the South, who wanted to sustain the existing system and to ensure a large supply of cheap (uneducated) labor.
} 
and human capital are significantly higher than in Guatemala and El Salvador, where coffee plantations are rather large. ${ }^{52}$ Moreover, one of the principles championed by the progressives during the Mexican Revolution of 1910 was compulsory free public education. However, the achievement of this goal varied greatly by state. In the north, where land distribution was more equitable, enrollment in public schools increased rapidly as industrialization advanced following the revolution. In contrast, the south, which was dominated by haciendas, employing essentially slave labor, there was virtually no increase in school enrollment following the revolution (Vaughan, 1982). Similarly, rural education in Brazil lagged behind some other Latin American countries due to the immense political power of the local landlords. Hence, in 1950, 30 years after the Brazilian government had instituted an educational reform, nearly $75 \%$ of the nation was still illiterate (Bonilla, 1965).

Moreover, the adverse effect of the concentration of land ownership on education expenditure has been established empirically. Galor et al. (2009) exploit exogenous source of variation in the concentration of land ownership across states in the US using data from the beginning of the twentieth century, they find that inequality in the distribution of land ownership indeed had an adverse effect on public investment in education. Becker et al. (2010, 2012) exploit variation in the concentration of land ownership across counties in Prussia and show that landownership was negatively related to educational enrolment in Prussia in 1816 and in 1849.

\subsubsection{Land Reforms and Education Reforms}

Evidence from Japan, Korea, Russia, and Taiwan indicates that land reforms were followed by, or occurred simultaneously with, significant education reforms. There are two interpretations for these historical episodes. First, land reforms could have diminished the economic incentives of landowners to block education reforms. Second, an unfavorable shift in the balance of power from the viewpoint of the landed aristocracy could have brought about the implementation of both land and education reforms, consistent with the basic premise that landowners opposed spending on education, whereas others (e.g., the industrial elite) favored it.

\footnotetext{
${ }^{52}$ In contrast to the proposed theory, Nugent and Robinson (2002) suggest that a holdup problem generated by the monopsonistic power in large plantations prevents commitment to reward investment in human capital, whereas smallholders can capture the reward to human capital and therefore have the incentive to invest. This mechanism does not generate the economic forces that permit the economy to escape this institutional trap.
} 
Japan and the Meiji Restoration Toward the end of the Tokugawa regime (1600-1867), although the level of education in Japan was impressive for its time, the provision of education was sporadic and had no central control or funding, reflecting partly the resistance of the landholding military class to education reforms (Gubbins, 1973). The opportunity to modernize the educational system arrived following the overthrow of the traditional feudal structure shortly after the Meiji Restoration of 1868. In 1871, an imperial decree initiated the abolishment of the feudal system. In a sequence of legislation during 1871-1883, decisions regarding land utilization and the choice of crops were transferred from landlords to farmers, prohibitions on the sale and mortgage of farmland were removed, a title of ownership was granted to the legal owners of the land, and communal pasture and forest land were transferred from the ownership of wealthy landlords to the ownership of the central government. This legislation resulted in the distribution of land among small family farms, a structure that persisted until the rise of a new landlord system during the 1930s (Hayami, 1975, chapter 3).

Education reform and land reform evolved simultaneously. In 1872 the Educational Code established compulsory and locally funded education for all children between the ages 6 and 14 (Gubbins, 1973). In addition, the central government funded a secondary school and university system. The Education Code of 1872 was refined in 1879 and 1886, setting the foundations for the structure of Japanese education until World War II. The progress in education attainment following the land reforms of the Meiji government was substantial: while in 1873 only $28 \%$ of school-age children attended schools, this ratio increased to $51 \%$ by 1883 and to $94 \%$ by 1903 (Passin, 1965).

Russia before the Revolution Education in tsarist Russia lagged well behind comparable European countries at the close of the nineteenth century. Provincial councils dominated by wealthier landowners were responsible for their local school systems and were reluctant to favor the education of the peasants (Johnson, 1969). Literacy rates in rural areas were $21 \%$ in 1896, and the urban literacy rate was $56 \%$. As the tsar's grip on power weakened during the early 1900s, the political power of the wealthy landowners gradually declined, leading to a sequence of agrarian reforms that were initiated by the Premier Pyotr Stolypin in 1906. Restrictions on the mobility of peasants were abolished, fragmented landholdings were consolidated, and the formation of individually owned farms was encouraged and supported through the provision of 
government credit. Stolypin's reforms accelerated the redistribution of land to individual farmers, and landholdings of the landed aristocracy declined from about 35-45\% in 1860 to $17 \%$ in 1917 (Johnson, 1969).

Following the agrarian reforms and the declining influence of the landed aristocracy, the provision of compulsory elementary education was proposed. The initial effort of 1906 languished, but the newly created representative body, the Duma, continued to pressure the government to provide free compulsory education. During the period 1908-1912, the Duma approved a sequence of significant increases in expenditures for education (Johnson, 1969). The share of the provincial council's budget that was allocated to education increased from $20 \%$ in 1905 to $31 \%$ in 1914 (Johnson, 1969), the share of the central government's budget devoted to the Ministry of Public Education increased threefold from $1.4 \%$ in 1906 to $4.9 \%$ in 1915 , and the share of the entire population that was actively attending schools increased threefold from $1.7 \%$ in 1897 to $5.7 \%$ in 1915 (Dennis, 1961).

South Korea and Taiwan The process of development in Korea was marked by major land reform followed by a massive increase in governmental expenditure on education. During the Japanese occupation in 1905-1945, land distribution in Korea became increasingly skewed, and by 1945 nearly 70\% of Korean farming households were simply tenants (Eckert, 1990). During the period 1948-1950, the Republic of Korea instituted the Agricultural Land Reform Amendment Act that drastically affected landholdings. ${ }^{53}$ The principle of land reform was enshrined in the constitution of 1948 and the actual implementation of the Agricultural Land Reform Amendment Act began on March 1950. ${ }^{54}$ This act prohibited tenancy and land renting, put a maximum on the amount of land any individual could own, and dictated that individuals could only own land if they actually cultivated it. Owner cultivated farm households increased sixfold from 349,000 in 1949 to $1,812,000$ in 1950, and tenant farm households declined from 1,133,000 in 1949 to essentially 0 in 1950 (Yoong-Deok and Kim, 2000).

Land reforms were accompanied by soaring expenditures on education. In 1949, a new Education Law was passed in South Korea that focused specifically on transforming the popu-

\footnotetext{
${ }^{53} \mathrm{~A}$ major force behind this land reform was the aim of the post-World War II U.S. provisional government to remove the influence of the large landowners (who were either Japanese or collaborators with the Japanese).

${ }^{54}$ Formally, education reform took place prior to the land reforms, but the provision for land reform was enshrined in the constitution prior to educational reform. The imminent land reform could have reduced the incentives for the landed aristocracy to oppose this education reform.
} 
lation into a technically competent workforce capable of industrial work. This legislation led to dramatic increases in the number of schools and students at all levels of education. Between 1945 and 1960, the number of elementary schools increased by $60 \%$, and the number of elementary students went up by a staggering $165 \%$. In secondary education, the growth was even more dramatic, with both the number of schools and the number of students growing by a factor of ten. The number of higher education institutions quadrupled, and that of higher education students increased from only 7,000 in 1945 to more than 100,000 in 1960. In 1948, Korea allocated 8\% of government expenditures to education. Following a slight decline due to the Korean War, educational expenditure increased to $9 \%$ in 1957 and to $15 \%$ in 1960, remaining at that level thereafter (Sah-Myung, 1983).

Taiwan experienced similar reforms during the same period, once Japanese colonization ended. The government of Taiwan implemented reforms during 1949-1953, enforcing rent reductions, selling public land to individual farmers who had previously been tenants, and permitting the purchase of rented land. In 1948, prior to these reforms, $57 \%$ of farm families were full or part owners, and $43 \%$ were tenants or hired hands; by 1959, the share of full or part owners had increased to $81 \%$, and the share of tenants had dropped to $19 \%$ (Chen, 1961).

A massive education reform accompanied these land reforms. The number of schools in Taiwan grew by 5\% per year between 1950 and 1970, while the number of students grew by $6 \%$ per year. The pattern of growth mirrors that of South Korea, with an especially impressive growth of $11 \%$ per year in the number of secondary students and $16 \%$ per year in higher education students. Funding for education grew from 1.8\% of GNP in 1951 to $4.1 \%$ in 1970 (Lin, 1983).

In 1950 South Korea and Taiwan were primarily agricultural economies with a GDP per capita (measured in 1990 international dollars) of about $\$ 770$ and $\$ 940$, respectively. South Korea and Taiwan's GDP per capita lagged well behind many countries in Latin America, such as Colombia $(\$ 2150)$ and Mexico $(\$ 2360)$, despite sharing with these countries a legacy of vast inequality in the distribution of agricultural land. In contrast to the Latin American countries, the implementation of land reforms in South Korea and Taiwan and its association with education reforms contributed to their tremendous growth performance in the post-war period. With a level of income per capita in 1950 that placed them not only far behind the nations of Latin America but also behind Congo, Liberia, and Mozambique, these two countries have each grown at an average rate of nearly $6 \%$ per year between 1950 and 1998, leaving behind the countries of sub- 
Saharan Africa and overtaking the Latin American countries. In 1998, South Korea and Taiwan had GDP per capita levels that were 150\% higher than that of Colombia and 100\% higher than in Mexico (Maddison, 2001).

\subsubsection{Political and Education Reforms}

The nineteenth century was marked by significant political reforms along with the previously described education reforms and impressive human capital formation. One could therefore challenge the significance of the industrial motive for educational reform, suggesting that political reforms during the nineteenth century shifted the balance of power toward the working class and enabled workers to implement education reforms independently of the interests of the industrial elite. Have political institutions, rather than changes in economic incentives in the process of development, been the prime force behind the formation of human capital during this period?

Political reforms that took place in the nineteenth century had no apparent effect on education reforms during this period, strengthening the hypothesis that industrial development, and the increasing demand for human capital, were indeed the trigger for human capital formation and the subsequent onset of the demographic transition. Education reforms took place in autocratic states that did not relinquish political power throughout the nineteenth century, and major reforms occurred in societies in the midst of the process of democratization well before the stage at which the working class constituted the majority of voters.

In particular, as depicted in Figure 7, the most significant education reforms in England were completed before the voting majority shifted to the working class. The Reform Act of 1832 nearly doubled the total electorate, but only $13 \%$ of the voting-aged population was enfranchised. Artisans, the working classes, and some sections of the lower middle classes remained outside the political system. The franchise was extended further by the Reform Acts of 1867 and 1884, and the total electorate nearly doubled in each of these episodes. However, working-class voters did not become the majority in all urban counties until 1884 (Craig, 1989).

Figure 7 shows that a trend of significant increases in primary education was established well before the extension of the voting rights in the context of the 1867 and 1884 Reform Acts. In particular, the proportion of children aged 5-14 in primary schools increased fivefold (and surpassed 50\%) over the three decades prior to the extension of the franchise in 1884 in which the working class was granted a majority in all urban counties. Furthermore, the political reforms 
do not appear to have had an effect on the pattern of educational reform. In fact, the average growth rate of school attendance from decade to decade during 1855-1920 reached a peak around the Reform Act of 1884 and started declining thereafter. It is interesting to note, however, that the abolition of education fees in nearly all elementary schools occurred only in 1891, after the Reform Act of 1884, suggesting that the political power of the working class may have affected the distribution of education cost across the population, but the decision to educate the masses appears to be taken independently of the political power of the working class.

Thus, the onset of England's education reforms, and in particular, the fundamental Education Act of 1870 and its major extension in 1880, occurred prior to the political reforms of 1884 that made the working class the majority in most counties. Moreover, while the shadow of the rebellion of the masses that may have prompted political reforms may have also contributed to education reforms (as established in Section 2.3.1), industrial demand for human capital in the second phase of industrialization dominated sociopolitical concerns in human capital formation.
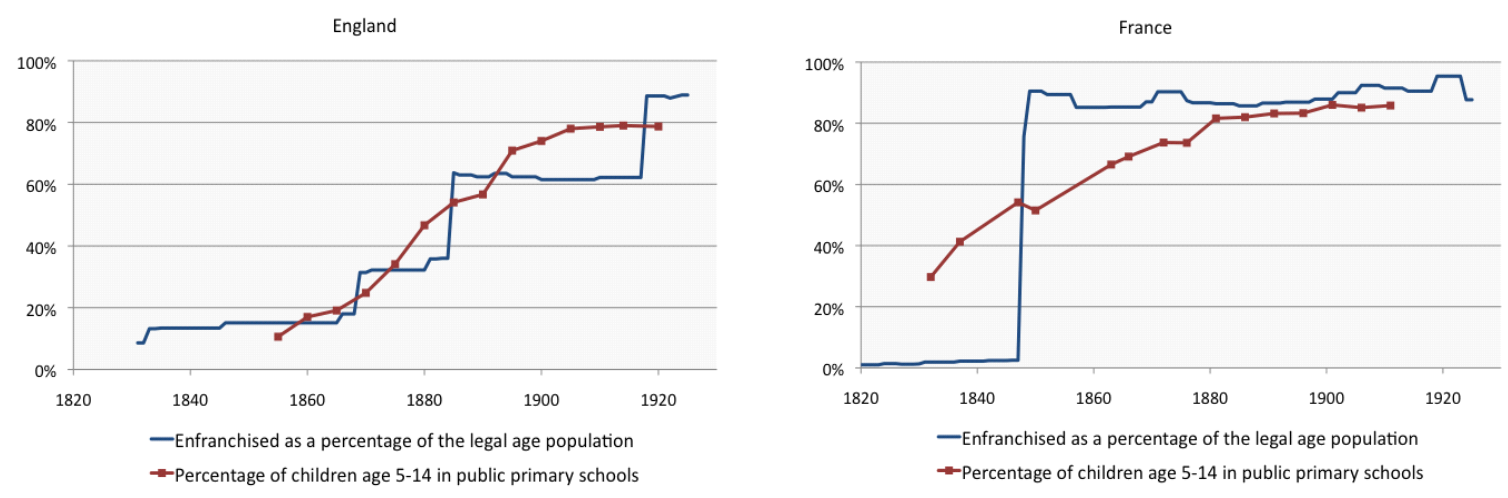

Figure 7. Evolution of voting rights and school enrollment.

Data source: Flora et al. (1983).

In France the trend of expanding education also preceded the major political reforms that gave the voting majority to the working class (Figure 7). Prior to 1848, restrictions limited the electorate to less than $2.5 \%$ of the voting-aged population. The 1848 revolution led to the introduction of universal voting rights for nearly all adult males and resulted in a majority for working class voters. Nevertheless, the proportion of children aged 5-14 in primary schools doubled (and exceeded 50\%) during the two decades prior to the extension of the franchise in 
1848. Furthermore, the political reforms of 1848 did not appear to have an effect on the pattern of education expansion.

A similar pattern occurred in other European countries. Political reforms in the Netherlands did not affect the trend in education expansion, and the proportion of children aged 5-14 in primary schools exceeded $60 \%$ well before the major political reforms of 1887 and 1897. Similarly, the trends of political and education reforms in Sweden, Italy, Norway, Prussia, and Russia do not lend credence to the alternative hypothesis. ${ }^{55}$

\section{Concluding Remarks}

Conventional wisdom about the relationship between income distribution and economic development has been subjected to dramatic transformations in the past century. While Classical economists advanced the hypothesis that inequality is beneficial for economic development, the Neoclassical paradigm, which had subsequently dominated the field of macroeconomics, dismissed the Classical hypothesis and promoted the viewpoint that the study of income distribution has no significance for the understanding of macroeconomic activity and the growth process.

A metamorphosis in these perspectives has taken place in the past two decades. Theory and subsequent empirical evidence have demonstrated that income distribution does, in fact, have a significant impact on the growth process. Moreover, unlike the Classical viewpoint, which underlined the beneficial effects of inequality for the growth process, the modern perspective has highlighted the potential adverse effects of inequality on the process of development.

The replacement of physical capital accumulation by human capital accumulation as the prime engine of economic growth has changed the qualitative impact of inequality on the process of development. In early stages of industrialization, as physical capital accumulation was a prime source of economic growth, inequality enhanced the process of development by channeling resources towards individuals whose marginal propensity to save is higher. In later stages of development, however, as human capital has become the prime engine of economic growth, a more equal distribution of income, in the presence of credit constraints, has stimulated investment in human capital and promoted economic growth.

While the process of industrialization raised the importance of human capital in the produc-

\footnotetext{
${ }^{55}$ Relatedly, Galor et al. (2009) find a positve effect of of education on political reforms acrsss coutnries in the period 1960-2000.
} 
tion process, reflecting its complementarity with physical capital and technology, human capital accumulation has not benefited all sectors of the economy. Inequality in the ownership of factors of production has generated an incentive for some better-endowed agents to block the implementation of institutional changes and policies that promote human capital formation, resulting in a suboptimal level of investment in human capital from a growth perspective.

The transition from an agricultural to an industrial economy changed the nature of the main economic conflict in society. Unlike the agrarian economy, which was characterized by a conflict of interests between the landed aristocracy and the masses, the process of industrialization has brought about an additional conflict between the entrenched landed elite and the emerging capitalist elite. In light of a lower degree of complementarity between human capital and the agricultural sector, education has increased the productivity of labor in industrial production more than in agricultural and primary good production, inducing rural-to-urban migration and thus a decline in the rental rate. Thus, while industrialists have had a direct economic incentive to support education policies that would foster human capital formation, landowners, whose interests lay in the reduction of the mobility of their labor force, have favored policies that deprived the masses of education, as long as their stake in the productivity of the industrial sector was insufficient. The adverse effect of the implementation of public education on landowners' income from agricultural production has been magnified by the concentration of land ownership. Thus, as long as landowners affected the political process and thereby the implementation of growthenhancing education policies, inequality in the distribution of land ownership has been a hurdle for human capital accumulation, slowing the process of industrialization and the transition to modern growth.

Economies in which land and other natural resources have been more equally distributed have implemented earlier public education campaigns and have benefited from the emergence of a skill-intensive industrial sector and a rapid process of development. In contrast, among economies marked by a more unequal distribution of ownership over land and other natural resources, resource abundance that was a source of richness in the early stages of development has led in later stages to under-investment in human capital, an unskilled labor-intensive industrial sector, and a slower growth process. Thus, variation in the distribution of ownership over land and other natural resources across countries has contributed to disparity in human capital formation and the industrial composition of the economy, and thus to divergent development patterns across the 
globe. Moreover, geographical conditions that led to income inequality brought about oppressive institutions designed to maintain the political power of the elite and to preserve the existing inequality . 


\section{References}

Abramovitz, M. and David, P. A. (2000). American macroeconomic growth in the era of knowledge-based progress: The long-run perspective, in S. L. Engerman and R. E. Gallman (eds), The Cambridge Economic History of the United States, Vol. 2, Cambridge University Press, New York, NY.

Acemoglu, D. (1998). Why Do New Technologies Complement Skills? Directed Technical Change and Wage Inequality*, Quarterly Journal of Economics 113(4): 1055-1089.

Acemoglu, D., Johnson, S. and Robinson, J. A. (2005). Institutions as the fundamental cause of long-run growth, in P. Aghion and S. N. Durlauf (eds), Handbook of Economic Growth, Vol IA, Elsevier North-Holland, Amsterdam, The Netherlands.

Acemoglu, D. and Robinson, J. A. (2000). Why did the West Extend the Franchise? Democracy, Inequality, and Growth in Historical Perspective, Quarterly Journal of Economics 115(4): 1167-1199.

Aghion, P. and Bolton, P. (1997). A Theory of Trickle-Down Growth and Development, Review of Economic Studies 64(2): 151-172.

Alesina, A. and Perotti, R. (1996). Income Distribution, Political Instability, and Investment, European Economic Review 40(6): 1203-1228.

Alesina, A. and Rodrik, D. (1994). Distributive Politics and Economic Growth, The Quarterly Journal of Economics 109(2): 465-490.

Anderson, R. D. (1975). Education in France 1848-1870, Clarendon Press, Oxford.

Autor, D. H., Katz, L. F. and Kearney, M. S. (2008). Trends in US Wage Inequality: Revising the Revisionists, The Review of Economics and Statistics 90(2): 300-323.

Baldwin, R. E. (1956). Patterns of Development in Newly Settled Regions, Manchester School of Economic and Social Studies 24(2): 161-179.

Banerjee, A. A. and Duflo, E. (2003). Inequality and growth: What can the data say?, Journal of economic growth 8(3): 267-299. 
Banerjee, A. and Newman, A. (1993). Occupational choice and the process of development, Journal of Political Economy 101(2): 274-298.

Barro, R. J. (2000). Inequality and Growth in a Panel of Countries, Journal of economic growth 5(1): $5-32$.

Becker, S. O., Cinnirella, F. and Woessmann, L. (2010). The trade-off between fertility and education: Evidence from before the demographic transition, Journal of Economic Growth 15(3): 177 Ü-204.

Becker, S. O., Cinnirella, F. and Woessmann, L. (2012). The effect of investment in childrenŠs education on fertility in 1816 prussia, Cliometrica $6(1)$.

Becker, S. O., Hornung, E. and Woessmannand, L. (2011). Education and Catch Up in the Industrial Revolution, American Economic Journal: Macroeconomics $\mathbf{3}$.

Benabou, R. (1996). Equity and efficiency in human capital investment: the local connection, Review of Economic Studies 63: 237-264.

Benabou, R. (2000). Unequal Societies: Income Distribution and the Social Contract, American Economic Review 90(1): 96-129.

Benabou, R. (2002). Tax and Education Policy in a Heterogeneous-Agent Economy: What Levels of Redistribution Maximize Growth and Efficiency?, Econometrica 70(2): 481-517.

Berman, E., Bound, J. and Machin, S. (1998). Implications of Skill-Biased Technological Change: International Evidence, Quarterly Journal of Economics 113(4): 1245-1279.

Bonilla, F. (1965). Brazil, in J. S. Coleman (ed.), Education and Political Development, Princeton University Press, Princeton.

Bourguignon, F. (1981). Pareto Superiority of Unegalitarian Equilibria in Stiglitz's Model of Wealth Distribution with Convex Saving Function, Econometrica 49(6): 1469-1475.

Bourguignon, F. and Verdier, T. (2000). Oligarchy, Democracy, Inequality and Growth, Journal of development Economics 62(2): 285-314.

Bowles, S. and Gintis, H. (1975). Capitalism and Education in the United States, Socialist Revolution 5(25): 101-138. 
Brezis, E. S. and Temin, P. (2008). Elites and Economic Outcomes, in S. N. Durlauf and L. E. Blume (eds), New Palgrave Dictionary of Economics, Macmillan, Basingstoke.

Cameron, R. (1993). A Concise Economic History of the World: From Paleolithic Times to the Present, Oxford University Press, USA.

Caselli, F. (1999). Technological Revolutions, American Economic Review 89(1): 78-102.

Checchi, D., Ichino, A. and Rustichini, A. (1999). More Equal but Less Mobile? Education Financing and Intergenerational Mbility in Italy and in the US, Journal of Public Economics 74(3): 351-393.

Chen, C. (1961). Land Reform in Taiwan, China Publishing Company, Taiwan.

Chou, C. and Talmain, G. (1996). Redistribution and Growth: Pareto Improvements, Journal of Economic Growth 1(4): 505-523.

Cipolla, C. M. (1969). Literacy and Development in the West, Penguin Books, Harmondsworth, Middlesex.

Clark, G. (2005). The Condition of the Working Class in England, 1209-2004, Journal of Political Economy 113(6): 1307-1340.

Coatsworth, J. H. (1993). Notes on the Comparative Economic History of Latin America and the United States, in W. Bernecker and H. W. Tobler (eds), Development and Underdevelopment in America, Walter de Gruyter, New York.

Crafts, N. (1985). British Economic Growth during the Industrial Revolution, Oxford University Press, Oxford.

Craig, F. W. S. (1989). British Electoral Facts, 1832-1987, Gower Press, Brookfield.

Cubberley, E. P. (1991). The History of Education, Reverside Press, Cambridge, MA.

Dahan, M. and Tsiddon, D. (1998). Demographic Transition, Income Distribution, and Economic Growth, Journal of Economic Growth 3(1): 29-52.

de la Croix, D. and Doepke, M. (2003). Inequality and Growth: Why Differential Fertility Matters, American Economic Review 93(4): 1091-1113. 
Deininger, K. and Squire, L. (1998). New Ways of Looking at Old Issues: Inequality and Growth, Journal of Development Economics 57(2): 259-288.

Dennis, G. (1961). Education, in M. T. Florinsky (ed.), Encyclopedia of Russia and the Soviet Union, McGraw-Hill, New York, NY.

Doepke, M. and Zilibotti, F. (2005). The Macroeconomics of Child Labor Regulation, American Economic Review 95(5): 1492-1524.

Durlauf, S. N. (1996a). A theory of persistent income inequality, Journal of Economic Growth 1(1): 75-93.

Durlauf, S. N. (1996b). Neighborhood feedbacks, endogenous stratification, and income inequality, in: W. Barnett, G. Gandolfo and C. Hillinger, Eds., Dynamic Disequilibrium Modelling, Cambridge University Press, Amsterdam .

Easterly, W. (2007). Inequality does Cause Underdevelopment: Insights from a New Instrument, Journal of Development Economics 84(2): 755-776.

Eckert, C. (1990). Korea Old and New: A History, Ilchokak, Seoul.

Eicher, T. S., García-Peñalosa, C. and van Ypersele, T. (2009). Education, Corruption, and the Distribution of Income, Journal of Economic Growth 14(3): 205-231.

Engerman, S. L. and Sokoloff, K. L. (2000). History Lessons: Institutions, Factor Endowments, and Paths of Development in the New World, Journal of Economic Perspectives 14(3): 217232 .

Fernandez, R., Guner, N. and Knowles, J. (2005). Love and Money: A Theoretical and Empirical Analysis of Household Sorting and Inequality*, Quarterly Journal of Economics 120(1): 273344.

Fernández, R. and Rogerson, R. (1996). Income Distribution, Communities, and the Quality of Public Education, Quarterly Journal of Economics 111(1): 135-164.

Fernández, R. and Rogerson, R. (2001). Sorting and Long-Run Inequality*, Quarterly Journal of Economics 116(4): 1305-1341. 
Fershtman, C., Murphy, K. M. and Weiss, Y. (1996). Social Status, Education, and Growth, Journal of Political Economy 104(1): 108-132.

Field, A. (1976). Educational Reform and Manufacturing Development in Mid-Nineteenth Century Massachusetts, Journal of Economic History 36(1): 263-266.

Flora, P., Kraus, F. and Pfenning, W. (1983). State Economy and Society in Western Europe 1815-1975, Volume 1.

Foellmi, R. and Zweimuller, J. (2006). Income Distribution and Demand-Induced Innovations, Review of Economic Studies 73(4): 941-960.

Forbes, K. J. (2000). A Reassessment of the Relationship between Inequality and Growth, American Economic Review 90(4): 869-887.

Foster, A. D. and Rosenzweig, M. R. (1996). Technical Change and Human-Capital Returns and Investments: Evidence from the Green Revolution, American Economic Review 86(4): 931953.

Galiani, S., Heymann, D., Dabús, C. and Tohmé, F. (2008). On the Emergence of Public Education in Land-Rich Economies, Journal of Development Economics 86(2): 434-446.

Galor, O. (2010). The 2008 Lawrence R. Klein Lecture - Comparative Economic Development: Insights from Unified Growth Theory, International Economic Review 51(1): 1-44.

Galor, O. (2011). Unified Growth Theory, Princeton University Press, Princeton, NJ.

Galor, O. and Moav, O. (2000). Ability-Biased Technological Transition, Wage Inequality, and Economic Growth, Quarterly Journal of Economics 115(2): 469-497.

Galor, O. and Moav, O. (2002). Natural Selection and the Origin of Economic growth, Quarterly Journal of Economics 117(4): 1133-1191.

Galor, O. and Moav, O. (2004). From Physical to Human Capital Accumulation: Inequality and the Process of Development, Review of Economic Studies 71(4): 1001-1026.

Galor, O. and Moav, O. (2006). Das Human-Kapital: A Theory of the Demise of the Class Structure, Review of Economic Studies 73(1): 85-117. 
Galor, O., Moav, O. and Vollrath, D. (2009). Inequality in Landownership, the Emergence of Human-Capital Promoting Institutions, and the Great Divergence, Review of Economic Studies 76(1): 143-179.

Galor, O. and Mountford, A. (2008). Trading Population for Productivity: Theory and Evidence, Review of Economic Studies 75(4): 1143-1179.

Galor, O. and Tsiddon, D. (1997a). Technological Progress, Mobility, and Economic Growth, American Economic Review 87(3): 363-382.

Galor, O. and Tsiddon, D. (1997b). The Distribution of Human Capital and Economic Growth, Journal of Economic Growth 2(1): 93-124.

Galor, O. and Weil, D. N. (1996). The Gender Gap, Fertility, and Growth, American Economic Review 86(3): 374-387.

Galor, O. and Weil, D. N. (1999). From Malthusian Stagnation to Modern Growth, American Economic Review 89(2): 150-154.

Galor, O. and Weil, D. N. (2000). Population, Technology, and Growth: From Malthusian Stagnation to the Demographic Transition and Beyond, American Economic Review 90(4): 806828.

Galor, O. and Zang, H. (1997). Fertility, Income Distribution, and Economic Growth: Theory and Cross-Country Evidence, Japan and the World Economy 9(2): 197-229.

Galor, O. and Zeira, J. (1988). Income Distribution and Investment in Human Capital: Macroeconomics Implication. Working Paper No. 197, Department of Economics, Hebrew University.

Galor, O. and Zeira, J. (1993). Income Distribution and Macroeconomics, Review of Economic Studies 60(1): 35-52.

Goldin, C. (1998). America's Graduation from High School: The Evolution and Spread of Secondary Schooling in the Twentieth Century, Journal of Economic History 58(2): 345-374.

Goldin, C. and Katz, L. F. (1998). The Origins of Technology-Skill Complementarity, Quarterly Journal of Economics 113(3): 693-732. 
Goldin, C. and Katz, L. F. (2001). The Legacy of US Educational Leadership: Notes on Distribution and Economic Growth in the 20th Century, American Economic Review 91(2): 18-23.

Gradstein, M. (2007). Inequality, Democracy and the Protection of Property Rights, Economic Journal 117(516): 252-269.

Green, A. (1990). Education and State Formation, Macmillan, Hampshire, UK.

Gubbins, J. H. (1973). The Making of Modern Japan, Scholarly Resources, Wilmington, DE.

Hanushek, E. A. (1992). The Trade-Off between Child Quantity and Quality, Journal of Political Economy 100(1): 84-117.

Hassler, J. and Mora, J. V. R. (2000). Intelligence, Social Mobility, and Growth, American Economic Review 90(4): 888-908.

Hassler, J., ose V. Rodriguez Mora and Zeira, J. (2007). Inequality and Mobility, Journal of Economic Growth 12(3): 235-259.

Hayami, Y. (1975). A Century of Agricultural Growth in Japan, University of Minnesota Press, Minneapolis.

Hurt, J. (1971). Education in Evolution, Paladin, London.

Johnson, W. (1969). Russia's Educational Heritage, Octagon Books, New York.

Kaldor, N. (1955). Alternative Theories of Distribution, Review of Economic Studies 23(2): 83100.

Kremer, M. and Chen, D. (2002). Income Distribution Dynamics with Endogenous Fertility, Journal of Economic Growth 7(3): 227-258.

Kurian, G. (1994). Datapedia of the United States, 1790-2000: America Year by Year, Bernan Press, Lanham, Md.

Kuznets, S. (1955). Economic Growth and Income Inequality, American Economic Review 45(1): 1-28.

Landes, D. S. (1969). The Unbound Prometheus: Technical Change and Industrial Development in Western Europe from 1750 to the Present, Cambridge University Press. 
Levine, R. (2005). Finance and Growth: Theory and Evidence, Handbook of Economic Growth 1: $865-934$.

Lewis, A. W. (1954). Economic Development with Unlimited Supplies of Labour, The Manchester School 22(2): 139-191.

Lin, C. J. (1983). The Republic of China (Taiwan), in R. M. Thomas and T. N. Postlethwaite (eds), Schooling in East Asia, Pergamon Press, Oxford.

Lizzeri, A. and Persico, N. (2004). Why Did the Elites Extend the Suffrage? Democracy and the Scope Of Government, with an Application to Britain's HAge Of Reform $\check{T}^{*}$, Quarterly Journal of Economics 119(2): 707-765.

Loury, G. C. (1981). Intergenerational Transfers and the Distribution of Earnings, Econometrica 49(4): 843-867.

Maddison, A. (2001). The World Economy: A Millennial Perspective, OECD, Paris.

Maoz, Y. D. and Moav, O. (1999). Intergenerational Mobility and the Process of Development, Economic Journal 109(458): 677-697.

Matsuyama, K. (2000). A Ricardian Model with a Continuum of Goods under Nonhomothetic Preferences: Demand Complementarities, Income Distribution, and North-South Trade, Journal of Political Economy 108(6): 1093-1120.

McClelland, C. (1980). State, Society, and University in Germany, 1700-1914, Cambridge University Press Cambridge, UK.

Mejía, D. and Posada, C.-E. (2007). Populist policies in the transition to democracy, European Journal of Political Economy 23(4): 932-953.

Mejía, D. and St-Pierre, M. (2008). Unequal Opportunities and Human Capital Formation, Journal of Development Economics 86(2): 395-413.

Mitch, D. F. (1992). The Rise of Popular Literacy in Victorian England: The Influence of Private Choice and Public Policy, University of Pennsylvania Press, Philadelphia.

Mitch, D. F. (1993). The role of human capital in the first industrial revolution, in J. Mokyr (ed.), The British Industrial Revolution: an Economic Perspective, Westview Press, Boulder. 
Moav, O. (2002). Income Distribution and Macroeconomics: The Persistence of Inequality in a Convex Technology Framework, Economics Letters 75(2): 187-192.

Moav, O. (2005). Cheap Children and the Persistence of Poverty, Economic Journal 115(500): 88110.

Mokyr, J. (2001). The Rise and Fall of the Factory System: Technology, Firms, and Households Since the Industrial Revolution, Carnegie-Rochester Conference Series on Public Policy 55(1): 1-45.

Mookherjee, D. and Ray, D. (2003). Persistent Inequality, Review of Economic Studies 70(2): 369393.

Murphy, K. M., Shleifer, A. and Vishny, R. (1989). Income Distribution, Market Size, and Industrialization, Quarterly Journal of Economics 104(3): 537-564.

Nelson, R. R. and Phelps, E. S. (1966). Investment in Humans, Technological Diffusion, and Economic Growth, American Economic Review 51(2): 69-75.

North, D. C. (1959). Agriculture in Regional Economic Growth, Journal of Farm Economics 41(5): 943-951.

Nugent, J. and Robinson, J. (2002). Are Endowments Fate?, CEPR Discussion Paper No. 3206

Owen, A. L. and Weil, D. N. (1998). Intergenerational Earnings Mobility, Inequality and Growth, Journal of Monetary Economics 41(1): 71-104.

Passin, H. (1965). Japan, in J. S. Coleman (ed.), Education and Political Development, Princeton University Press, Princeton.

Perotti, R. (1996). Growth, Income Distribution, and democracy: what the Data say, Journal of Economic growth 1(2): 149-187.

Persson, T. and Tabellini, G. (1994). Is Inequality Harmful for Growth?, American Economic Review 84(3): 600-621.

Piketty, T. (1997). The Dynamics of the Wealth Distribution and the Interest Rate with Credit Rationing, The Review of Economic Studies 64(2): 173-189. 
Quah, D. T. (1996). Convergence Empirics across Economies with (Some) Capital Mobility, Journal of Economic Growth 1(1): 95-124.

Rajan, R. G. (2009). Rent Preservation and the Persistence of Underdevelopment, American Economic Journal: Macroeconomics 1(1): 178-218.

Ringer, F. (1979). Education and Society in Modern Europe, Indiana University Press, Bloomington.

Rosenstein-Rodan, P. N. (1943). Problems of Industrialisation of Eastern and South-Eastern Europe, The Economic Journal 53(210): 202-211.

Rosenzweig, M. R. and Wolpin, K. I. (1980). Testing the Quantity-Quality Fertility Model: The Use of Twins as a Natural Experiment, Econometrica 48(1): 227-240.

Sah-Myung, H. (1983). The Republic of Korea (South Korea), in R. M. Thomas and T. N. Postlethwaite (eds), Schooling in East Asia, Pergamon Press, Oxford.

Saint-Paul, G. and Verdier, T. (1996). Inequality, redistribution and growth: A challenge to the conventional political economy approach, European Economic Review 40(3-5): 719-728.

Sanderson, M. (1995). Education, Economic Change, and Society in England, 1780-1870, Cambridge University Press, Cambridge, UK.

Schultz, T. W. (1975). The Value of the Ability to Deal with Disequilibria, Journal of Economic Literature pp. 827-846.

Simon, B. (1987). Systematization and Segmentation in Education: the Case of England, in D. Muller, F. Ringer and B. Simon (eds), The Rise of the Modern Educational System, Cambridge University Press, Cambridge.

Stiglitz, J. (1969). Distribution of Income and Wealth among Individuals, Econometrica 37(3): 382-397.

Vaughan, M. (1982). The State, Education, and Social Class in Mexico, 1880-1928, Northern Illinois University Press, DeKalb, IL.

Wolthuis, J. (1999). Lower Technical Education in the Netherlands, 1798-1993: The Rise and Fall of a Subsystem, Garant, Apeldoorn, The Netherlands. 
Yoong-Deok, J. and Kim, Y. (2000). Land Reform, Income Redistribution, and Agricultural Production in Korea, Economic Development and Cultural Change 48(2): 253-268.

Zilcha, I. (2003). Intergenerational Transfers, Production and Income Distribution, Journal of Public Economics 87(3-4): 489-513. 